\title{
Amygdalar Gating of Early Sensory Processing through Interactions with Locus Coeruleus
}

\author{
CCynthia D. Fast and John P. McGann \\ Behavioral and Systems Neuroscience, Department of Psychology, Rutgers University, Piscataway, New Jersey 08854
}

Fear- and stress-induced activity in the amygdala has been hypothesized to influence sensory brain regions through the influence of the amygdala on neuromodulatory centers. To directly examine this relationship, we used optical imaging to observe odor-evoked activity in populations of olfactory bulb inhibitory interneurons and of synaptic terminals of olfactory sensory neurons (the primary sensory neurons of the olfactory system, which provide the initial olfactory input to the brain) during pharmacological inactivation of amygdala and locus coeruleus (LC) in mice. Although the amygdala does not directly project to the olfactory bulb, joint pharmacological inactivation of the central, basolateral, and lateral nuclei of the amygdala nonetheless strongly suppressed odor-evoked activity in GABAergic inhibitory interneuron populations in the $\mathrm{OB}$. This suppression was prevented by inactivation of LC or pretreatment of the olfactory bulb with a broad-spectrum noradrenergic receptor antagonist. Visualization of synaptic output from olfactory sensory neuron terminals into the olfactory bulb of the brain revealed that amygdalar inactivation preferentially strengthened the odor-evoked synaptic output of weakly activated populations of sensory afferents from the nose, thus demonstrating a change in sensory gating potentially mediated by local inhibition of olfactory sensory neuron terminals. We conclude that amygdalar activity influences olfactory processing as early as the primary sensory input to the brain by modulating norepinephrine release from the locus coeruleus into the olfactory bulb. These findings show that the amygdala and LC state actively determines which sensory signals are selected for processing in sensory brain regions. Similar local circuitry operates in the olfactory, visual, and auditory systems, suggesting a potentially shared mechanism across modalities.

Key words: affective; amygdala; emotional; locus coeruleus; olfactory; sensory gating

\section{Significance Statement}

The affective state is increasingly understood to influence early neural processing of sensory stimuli, not just the behavioral response to those stimuli. The present study elucidates one circuit by which the amygdala, a critical structure for emotional learning, valence coding, and stress, can shape sensory input to the brain and early sensory processing through its connections to the locus coeruleus. One function of this interaction appears to be sensory gating, because inactivating the central, basolateral, and lateral nuclei of the amygdala selectively strengthened the weakest olfactory inputs to the brain. This linkage of amygdalar and LC output to primary sensory signaling may have implications for affective disorders that include sensory dysfunctions like hypervigilance, attentional bias, and impaired sensory gating.

\section{Introduction}

The sensory areas of the brain receive extensive projections from neuromodulatory centers in the brainstem and basal forebrain. These neuromodulatory regions are thought to play important

\footnotetext{
Received Sept. 5, 2016; revised Dec. 18, 2016; accepted Jan. 9, 2017.

Author contributions: C.D.F. and J.P.M. designed research; C.D.F. performed research; J.P.M. contributed unpublished reagents/analytic tools; C.D.F. and J.P.M. analyzed data; C.D.F. and J.P.M. wrote the paper.

This work was funded by Grants R01-MH-101293 from the National Institute of Mental Health and R01-DC-

013090 from the National Institute on Deafness and Other Communication Disorders to J.P.M.

The authors declare no competing financial interests.

Correspondence should be addressed to John P. McGann, Psychology Department, Rutgers University, 152

Frelinghuysen Road, Piscataway, NJ 08854. E-mail: john.mcgann@rutgers.edu.

DOI:10.1523/JNEUROSCI.2797-16.2017

Copyright $\odot 2017$ the authors $\quad 0270-6474 / 17 / 373085-17 \$ 15.00 / 0$
}

roles in sensory information processing by guiding attention, evoking neuroplasticity in sensory structures, and adapting sensory information processing to match the behavioral state of the organism (Aston-Jones et al., 1999; Gu, 2002; Froemke and Martins, 2011; Sara, 2015; Schwarz and Luo, 2015). Dysfunctional neuromodulation has been linked to mental disorders with sensory endophenotypes like hypervigilance, attentional dysregulation, and impaired sensorimotor gating (Maes et al., 1999; O’Donnell et al., 2004; Alsene et al., 2011; Hegerl and Hensch, 2014; Johnston et al., 2014; Hendrickson and Raskind, 2016). However, it remains unclear how the activity of these neuromodulatory structures is directed by other brain regions, and, thus, their role in normal and disordered sensory processing has been difficult to assess. 
One of the major influencers of the neuromodulatory structures of the brain is the amygdala (Price and Amaral, 1981; Aggleton, 1993; Retson and Van Bockstaele, 2013), a subcortical structure that is famously involved in affective processing, including the encoding of stimulus valence (Maren, 2016) and emotional learning about highly valenced stimuli (Johansen et al., 2011; Lee et al., 2013; Paz and Pare, 2013). Amygdala activation by direct stimulation (Chavez et al., 2013) or by naturally aversive stimuli can influence sensory processing (Taylor et al., 2000; Stark et al., 2004). Amygdala-dependent learning about neutral sensory stimuli (such as during fear conditioning) has been found to induce plasticity in virtually all sensory modalities (for review, see McGann, 2015), but it remains unclear how the amygdala influences precortical sensory regions that do not receive any direct amygdalar projections (Maren et al., 2001).

Affective experiences like fear conditioning engage the central, basolateral, and lateral (CBL) amygdalar subnuclei (Goosens and Maren, 2001), which are positioned to broadly influence the rest of the brain through the extensive projections of the central nucleus to neuromodulatory and neuroendocrine structures (Price and Amaral, 1981; Amaral and Price, 1984). Of these, the strong projection from central amygdala (CeA) to the locus coeruleus (LC; Van Bockstaele et al., 1999; Schwarz et al., 2015) is particularly intriguing because the LC has a similarly broad influence across sensory systems (Rogawski and Aghajanian, 1980; Kayama et al., 1982; Sato et al., 1989; George, 1992) and because the LC plays a distinctive role in arousal (Foote et al., 1980), vigilance (Aston-Jones et al., 1994; Rajkowski et al., 1994; Aston-Jones et al., 1998) and sensory gating (Waterhouse et al., 1988; Jiang et al., 1996; Rutter et al., 1998; Devilbiss et al., 2012; Hormigo et al., 2015). The central amygdala $\rightarrow$ LC circuit includes both excitatory and inhibitory connections (Van Bockstaele et al., 1998, 1999), forming a complex circuit that is activated by fear, stress, and anxiety (Valentino et al., 1992; Van Bockstaele et al., 1998; Berridge and Waterhouse, 2003; Moriceau et al., 2009; Devilbiss et al., 2012; Manella et al., 2013) and shapes learned attachment and fear during development (Landers and Sullivan, 2012).

We explored the interactions of the amygdala, LC, and sensory processing in the olfactory system, where emotional learning produces dramatic changes in sensory processing in both humans and animal models (Jones et al., 2008; Li et al., 2008; Chen et al., 2011; Fletcher, 2012; Kass et al., 2013d; Krusemark and Li, 2013; Dias and Ressler, 2014; Li, 2014) and where noradrenergic signaling has been shown to influence odor perception (Doucette et al., 2007; Escanilla et al., 2010; Linster et al., 2011), olfactory memory (Manella et al., 2013), neonatal olfactory preference (Sullivan and Wilson, 1991; McLean and Harley, 2004), and local circuit function (Jiang et al., 1996; Nai et al., 2009; Eckmeier and Shea, 2014). The olfactory bulb does not receive any direct projections from the amygdala, but we hypothesized that amygdalar influences on early sensory processing could nonetheless be observed in olfactory bulb glomeruli by way of the amygdala $\rightarrow$ LC $\rightarrow$ olfactory bulb circuit.

\section{Materials and Methods}

Subjects. The present study used a total of 41 experimentally naive adult mice (22 male and 19 female) ranging from 16 to 32 weeks of age. To visualize neural activity in GABAergic periglomerular (PG) interneurons, we crossed mice from the GAD2-IRES-Cre driver line (stock $\# 010802$, The Jackson Laboratory) that bicistronically expresses cre recombinase from the promoter for gad2, the gene that encodes glutamic acid decarboxylase 65 (GAD65; Taniguchi et al., 2011), with mice from the Ai95D reporter line (stock \#024105, The Jackson Laboratory) that include the calcium indicator GCaMP6f (Akerboom et al., 2012; Chen et al., 2013) sequence under control of the endogenous Gt(ROSA)26Sor promoter/enhancer regions and the CAG hybrid promoter but with a floxed STOP codon (Madisen et al., 2015). In the resulting offspring, cre-mediated recombination excises the STOP codon, resulting in the expression of GCaMP6f in GAD65-expressing cells throughout the brain, including periglomerular interneurons in the olfactory bulb, as previously reported (Kiyokage et al., 2010; Wachowiak et al., 2013). To visualize neurotransmitter release from olfactory sensory neurons (OSNs), we used a line of gene-targeted mice in which the coding region for olfactory marker protein (OMP) has been replaced with the sequence for the fluorescent exocytosis indicator synaptopHluorin $(\mathrm{spH})$ on an albino C57BL/6 background (Miesenböck et al., 1998; Bozza et al., 2004; Czarnecki et al., 2011). These mice were heterozygous for both $\mathrm{spH}$ and OMP (Kass et al., 2013b,c). All subjects were maintained on a $12 \mathrm{~h}$ light/ dark cycle with ad libitum access to rodent chow and water. All experiments were conducted in accordance with protocols approved by the Rutgers University Animal Care and Use Committee.

Cannula implantation, infusions, and histology. Mice were implanted with bilateral cannulae (22 g, $4 \mathrm{~mm}$ length; Plastics One) targeting the CBL amygdala (1.4 $\mathrm{mm}$ posterior to bregma, $3.2 \mathrm{~mm}$ lateral from midline, and $4.3 \mathrm{~mm}$ ventral from skull). Some mice also received bilateral cannulae ( $26 \mathrm{~g}, 1.8 \mathrm{~mm}$ center-to-center, $4.2 \mathrm{~mm}$ in length) targeting the LC (5.45 $\mathrm{mm}$ posterior to bregma, $0.9 \mathrm{~mm}$ lateral to midline, and 3.68 $\mathrm{mm}$ ventral from skull).

During microinfusion, internal cannulae (CBL, $28 \mathrm{~g}$; LC, $33 \mathrm{~g}$ ) that extended $0.8 \mathrm{~mm}$ beyond their respective guides were affixed to PE-20 polyethylene tubing that was mounted to $10 \mu \mathrm{l}$ Hamilton syringes positioned on a dual-channel infusion pump (Harvard Apparatus). Muscimol (Sigma-Aldrich; $2 \%$ in $0.1 \mathrm{~m} \mathrm{PBS} \mathrm{solution,} \mathrm{filtered} \mathrm{at} 0.20 \mu \mathrm{m}$ ) or vehicle (PBS) was infused at $0.25 \mu \mathrm{l} / \mathrm{min}$ for a $1 \mathrm{~min}$ total infusion period for CBL and $0.125 \mu \mathrm{l} / \mathrm{min}$ for a $1 \mathrm{~min}$ infusion period for LC with internals left in place for 1 additional minute to aid in diffusion. Some subjects also received $13.7 \mathrm{~mm}$ labetalol (impurity A 2-hydroxy-5-[1-hydroxy2[(1-methyl-3-phenylpropyl)-amino] ethyl] benzoic acid, LGC) or Ringer's solution vehicle topically applied to the dorsal surface of the olfactory bulb. Following data collection, an equivalent volume and concentration of muscimol with BODIPY TMR-X conjugate (Life Technologies) was infused at each target to enable the estimation of diffusion patterns and localization. Subjects were then perfused intracardially with $4 \%$ paraformaldehyde (PFA) followed by $0.1 \mathrm{M} \mathrm{PBS}$, tissue was extracted and stored in PFA until it was sectioned (100 $\mu \mathrm{m}$ coronal or horizontal) on a vibratome (Ted Pella), mounted on slides for the microscope, treated with ProLong with DAPI (Life Technologies), coverslipped, and viewed on a microscope (Olympus) equipped with the appropriate filter sets. Because of the physical differences between muscimol and BODIPY-tagged muscimol, the fact that the BODIPY-tagged muscimol was administered as a second infusion, and the possibility that the indicator may have spread during tissue processing, these histological methods can be expected to reliably show the centroid of the infusion (see Figs. $2,4)$ but only an approximation of the drug spread.

Optical imaging. Mice were prepared for olfactory bulb imaging as previously described (Czarnecki et al., 2012; Moberly et al., 2012; Kass et al., 2013a). Briefly, mice were deeply anesthetized using pentobarbital and dosed subcutaneously with atropine to reduce nasal secretions. An acrylic headcap was implanted to secure the mouse to the custom headholder, and the skull overlying the olfactory bulb was thinned bilaterally and topped with Ringer's solution and a coverslip. For mice receiving direct application of drug to the olfactory bulb, the skull and dura were instead removed and mice received dexamethasone subcutaneously to minimize brain swelling.

Mice were positioned under a custom microscope including an Olympus $4 \times$ macro objective with a 0.28 numerical aperture with epiillumination provided by a blue LED. Green fluorescence images were captured using a low read noise RedShirtImaging SM-256 CCD camera acquiring at $25 \mathrm{~Hz}$ at $256 \times 256$ resolution. Optical imaging was shotnoise limited. The odor methyl valerate (an ester used commercially as an artificial apple flavor) was presented by vapor dilution olfactometry with nitrogen as the carrier gas at a fixed concentration previously reported as 
8 arbitrary units in other studies from our laboratory (Kass et al., 2013d) and standardized daily with a photoionization detector. Odor presentations lasted for $6 \mathrm{~s}$ and were repeated a minimum of five times in each condition with a minimum of $60 \mathrm{~s}$ between trials. No-odor blank control trials were included to correct for fluorescence bleaching. Respiratory signals were monitored using a piezosensor pressed against the abdominal wall, which conveys the second derivative of intranasal airflow, as previously reported in the study by Kass et al. (2013d, their Supplementary Fig. 1).

Data analysis. Optical imaging data were analyzed as previously described (Kass et al., 2016). Briefly, optical data were spatially low-pass filtered with a $3 \times 3$ pixel median filter to minimize shot noise and gently spatially high-pass filtered with a two-dimensional Gaussian filter with an SD of $\sim 240 \mu \mathrm{m}$ to minimize contributions of diffuse metabolic signals or out-of-focus signals originating below the glomerular layer. Lowpass temporal filtering was applied at $9.38 \mathrm{~Hz}$ (GCaMP6f) or $6.25 \mathrm{~Hz}$ $(\mathrm{spH})$ to prevent aliasing artifacts. No photobleaching was observed in the GCaMP6f data, but spH data were blank subtracted to correct for bleaching. No movement correction was applied. We calculated odorevoked GCaMP signals as the difference between the fluorescence during odor presentation and baseline fluorescence before odor presentation normalized by preodor baseline $(\Delta F / F)$, but for $\mathrm{spH}$ we used the raw difference between odor and baseline $(\Delta F)$ because baseline fluorescence of $\mathrm{spH}$ reflects indicator molecules that are not sequestered to readily releasable vesicles (Bozza et al., 2004). In all GCaMP6f experiments, we tested for a drug-induced change in resting fluorescence, but none was observed, so these analyses are not reported on further. Odor response maps were calculated by subtracting the preodor baseline image from the image during the peak of the odor-evoked fluorescence during the first inhalation of odor (for GCaMP6f, which gives a moment-to-moment readout of neural activity) or at the end of the odor presentation (for $\mathrm{spH}$, which is an indicator of cumulative exocytosis). Pseudocolor scales for response maps were selected to show the full range of glomerular responses except in Figure 7, where the display of the largest glomerular responses was intentionally saturated to better visualize weakly activated glomeruli. The total area under the $\Delta F / F$ curve was also calculated for GCaMPf signals but gave very similar results (Fig. 1C). Glomerular regions of interest within the image were identified manually for each animal based on pre-drug infusion odor responses by a blind experimenter and applied uniformly to all trials. Responses on individual odor trials were quantified and candidate regions of interest were included if the mean signal over five trials was at least 3 SEs above zero.

Because some of the analyses include changes in small responses, we calculated the mean single trial signal-to-noise ratio (SNR) for each glomerulus for each of the five predrug trials that were averaged to create the scatter plot showing pooled data in Figure 6. SNR was defined as the square of the ratio of the root mean square fluorescence during the first 4 s of odor presentation to the root mean square fluorescence during the 4 s preodor baseline, that is $\left(\mathrm{RMS}_{\text {odor }} / \mathrm{RMS}_{\text {baseline }}\right)^{2}$. The average singletrial SNR for these 639 glomeruli was $263 \pm 14$, with an average singletrial odor-evoked signal of $4.9 \pm 0.0 \% \Delta F / F$ compared with a typical single-trial RMS baseline noise of $\sim 0.2 \% \Delta F / F$ before stimulus onset. The smallest individual glomerular response included in the analysis by our statistical methods exhibited a reliable odor response of $0.7 \% \Delta F / F$ compared with an RMS baseline noise of $0.2 \% \Delta F / F$, while the largest was an odor response of $15.4 \% \Delta F / F$. Because these odor-evoked responses were averaged over five trials before and five trials after each experimental manipulation, changes of $<0.1 \% \Delta F / F$ could be reliably detected.

Processing and quantification of optical data were performed using custom MATLAB software. Statistical analyses were performed using SPSS and Origin Pro 2016. Comparisons of both central tendency and distributional shape were planned a priori. All reported experiments tested parametric hypotheses, such as the interaction of drug/vehicle infusion with experimental stage or comparisons of group means to the null hypothesis of zero change, so parametric statistics were used throughout. Statistical $p$ values were Bonferroni corrected wherever multiple comparisons were made within the analysis of an individual experiment.

\section{Results}

Inactivation of the CBL amygdala inhibits GABAergic periglomerular interneuron populations in the olfactory bulb

The first stage of olfactory processing in the brain happens on the surface of the olfactory bulb, where the axon terminals of OSNs in the nose make synapses onto mitral cells and local interneurons within small spherical structures called glomeruli. Because each glomerulus receives axons only from OSNs expressing one particular odor receptor, odors that bind to different receptors drive activity in different odor-specific subsets of glomeruli, which thus constitute the initial representation of odor identity in the CNS. Previous work has shown that olfactory fear conditioning enhances odor-evoked responding in OSNs (Kass et al., 2013d) and mitral cells (Fletcher, 2012), possibly through alterations in the activity of GABAergic interneurons in the olfactory bulb (Okutani et al., 2002, 2003). We thus initially tested the effect of pharmacological inactivation of the amygdala on the olfactory signaling of PG interneurons in the olfactory bulb.

The activity of glomerular populations of PG cells was visualized in transgenic mice by expressing the fluorescent calcium indicator GCaMP6f in neurons expressing the gad2 gene, which encodes the GABA-synthesizing enzyme GAD65. Within the olfactory glomerulus, GAD65 is expressed selectively in PG cells (Shao et al., 2009; Kiyokage et al., 2010), resulting in GCaMP6f expression in all glomeruli in these PG-GCaMP mice, as previously reported (Wachowiak et al., 2013). Odor presentation in PG-GCaMP mice evokes respiration-locked increases in fluorescence in odor-specific subsets of olfactory bulb glomeruli. GAD65-expressing granule cell populations in the olfactory bulb likely make little or no contribution to this signal because their depth below the pial surface makes it unlikely that they are illuminated by the LED and because any fluorescence emissions from granule cells would likely produce a diffuse signal unlike the focal fluorescence increases observed here.

Fourteen PG-GCaMP mice were implanted with bilateral guide cannulae targeting the CBL nuclei of the amygdala $(\mathrm{CBL}$ amygdala), regions that are involved in affective processing and emotional learning. These mice were then implanted with optical windows over the olfactory bulb, and baseline glomerular PG cell responses to five odorant presentations were observed (Fig. $1 A, B)$. Muscimol (2\%), a $\mathrm{GABA}_{\mathrm{A}}$ receptor agonist commonly used to silence local activity (Martin and Ghez, 1999; Narayanan et al., 2006), or a vehicle control solution was then slowly infused $(0.25 \mu \mathrm{l} / \mathrm{min}$ for $1 \mathrm{~min})$ into the CBL amygdala and, after allowing $20 \mathrm{~min}$ for diffusion, five additional odor presentations were delivered. The effects of muscimol infusion differed from glomerulus to glomerulus (see below) but, on average, produced a significant reduction of odor-evoked responses compared with the preinfusion baseline $\left(t_{(309)}=-8.177\right.$, adjusted $p<0.001$; based on 310 glomeruli from 7 mice; Fig. $1 C$, left) that was replicated in multiple further experiments detailed below. Analysis of subsequent inhalations can be difficult to interpret because they are not necessarily independent of the initial response, but measurement of the total area under the curve for GCaMP signals across the whole odor presentation showed a very similar reduction $\left(t_{(309)}=-4.952\right.$, adjusted $p<0.001$; Fig. $1 C$, right $)$. Vehicle infusion into the CBL amygdala (Fig. $1 D-F$ ) induced a slight but statistically significant increase in odor-evoked PG cell activity $t_{(324)}=7.172$, adjusted $p<0.001$; based on 325 glomeruli from seven mice) that was significantly different from the decrease seen with muscimol $\left(F_{(1,633)}=74.835, p<0.001\right)$. Figure $1 G$ shows a representative example of the odor-evoked glomerular 
A

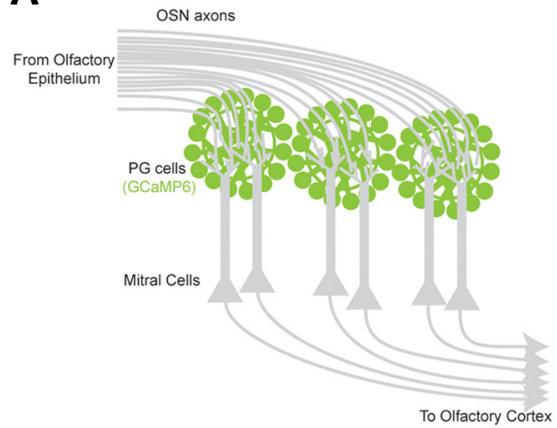

B

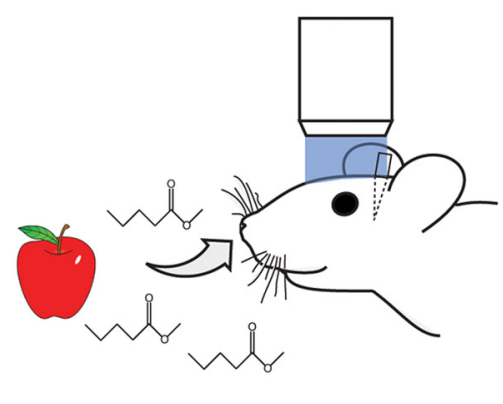

C

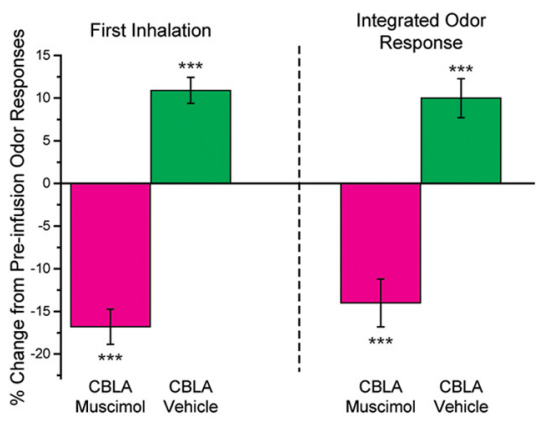

D

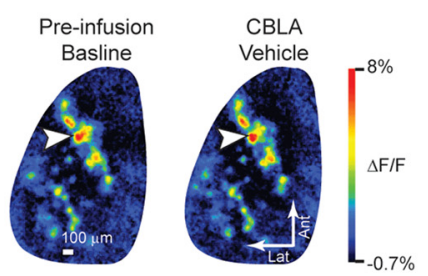

G

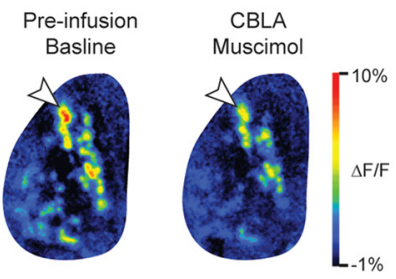

E

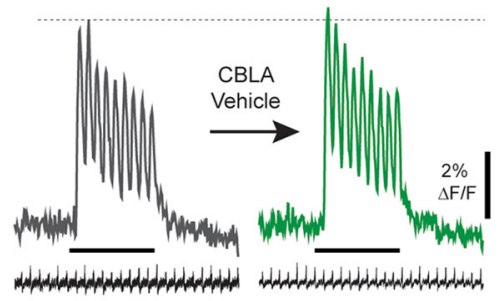

F
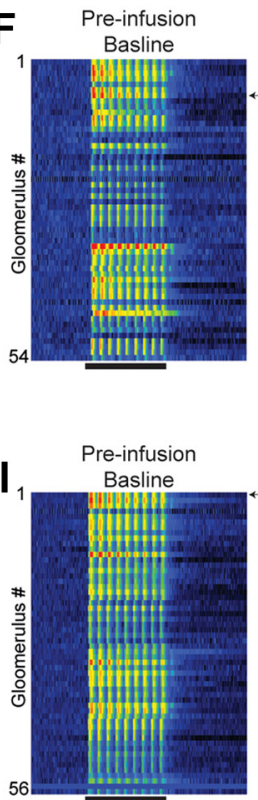
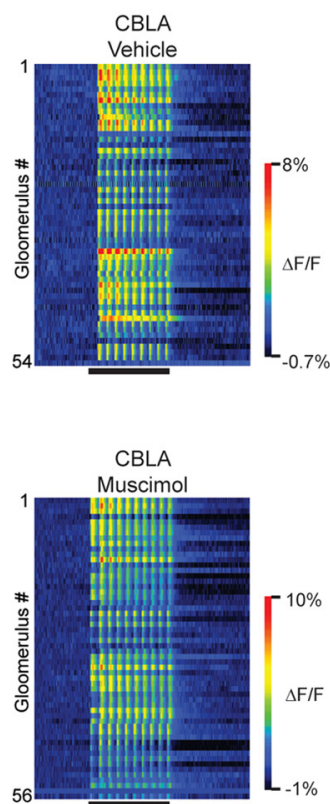

Figure 1. Inactivation of the amygdala inhibits GABAergic periglomerular interneuron populations in the olfactory bulb. $\boldsymbol{A}$, Schematic illustration of the first stage of olfactory processing on the surface of the olfactory bulb. Axons terminals from OSNs located in the olfactory epithelium synapse onto mitral cells (which project to the olfactory cortex) and local interneurons, including periglomerular cells (green), within small spherical structures called glomeruli. Odor-evoked activity of olfactory bulb PG interneurons was visualized in transgenic mice that expressed the fluorescent calcium indicator GCaMP6f in GABAergic PG cells. B, Mice were implanted with bilateral cannulae targeting the central, basal, and lateral nuclei of the amygdala (CBLA), and odor-evoked activity of $P G$ populations in individual glomeruli was observed through optical windows implanted over the olfactory bulbs. $C$, Infusing the $G A B A_{A}$ agonist muscimol into the $C_{B L}$ amygdala produced a significant reduction ( $p<0.001$ ) in odor-evoked activity (red bars) both during the first sniff of odorant (left) and integrated over the full $6 \mathrm{~s}$ odorant presentation (right). Vehicle infusion into (BL amygdala produced a slight but significant increase in odor-evoked activity (green bars). Error bars represent the SEM. ${ }^{* * *}$ Statistically significant change from the preinfusion baseline at the $p<$ 0.001 level. D, G, Pseudocolored activity maps showing the change in fluorescence of the olfactory bulb during the first inhalation of odorant before and after (BL amygdala infusions of vehicle (D) or muscimol $(\boldsymbol{G})$. $\boldsymbol{E}, \boldsymbol{H}$, Traces indicating the change in fluorescence over time from the glomeruli indicated by arrows in $\boldsymbol{D}$ and $\boldsymbol{G}$ during odor presentations before (gray trace) and following (BL amygdala infusion of vehicle ( $\boldsymbol{E}$, green trace) or muscimol $(\boldsymbol{H}$, red trace). Black bars indicate the delivery of odorant for 6 s. Small black traces indicate respiration frequency, with upticks reflecting inhalation. $\boldsymbol{F}, \boldsymbol{I}$, Pseudocolored heat maps depicting the change in fluorescence in all responsive glomeruli (along the ordinate) over time (on the abscissa) before and after vehicle ( $\boldsymbol{F}$ ) or muscimol (I) infusion into CBL amygdala for the example mouse shown in $\boldsymbol{D}$ and $\boldsymbol{G}$. The arrows denote which line of each heat map corresponds to the glomeruli illustrated in $\boldsymbol{D}$ and $\boldsymbol{G}$. Lat, Lateral; Ant, anterior.

PG cell activity during the initial inhalation of odorant before and after CBL amygdala inactivation, along with examples of the time course of calcium dynamics within an individual glomerulus (Fig. $1 H, I$ ). To confirm cannula targeting, after completing the imaging experiment we delivered a second infusion that was identical to the first but instead used muscimol tagged with BODIPY, which was not used in the initial infusion to ensure effective pharmacological action at $\mathrm{GABA}_{\mathrm{A}}$ receptors, to visualize the approximate spread of infusate. Subsequent histology confirmed effective targeting of the CBL amygdala in both vertical and horizontal planes (Fig. $2 A-C$ ) and showed that the spread of muscimol was approximately confined to the relevant nuclei (though this is best viewed as a minimum spread given the larger molecular weight and thus reduced diffusion of the tagged muscimol). The cortical and medial nuclei, which receive projections from the olfactory bulb (but do not project to the olfactory bulb), were spared.

Inactivation of the locus coeruleus prevents the effect of $\mathrm{CBL}$ amygdala inactivation on PG cells

Olfactory bulb glomeruli receive extensive descending noradrenergic projections from the locus coeruleus (Fallon and Moore, 1978; Shipley et al., 1985; McLean et al., 1989), which is richly innervated by the central nucleus of the amygdala (Van Bockstaele et al., 1998, 1999; Reyes et al., 2008; Retson and Van Bockstaele, 2013). We thus hypothesized that the observed effects of CBL amygdala inactivation on PG cells occurred through amygdalar effects on the LC. To test this hypothesis, we examined whether inactivation of the LC via local muscimol infusion would prevent the effect of CBL amygdala inactivation on PG cells in the 
A

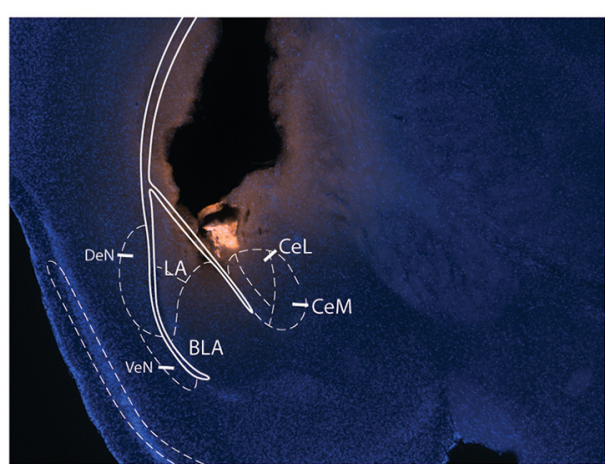

B
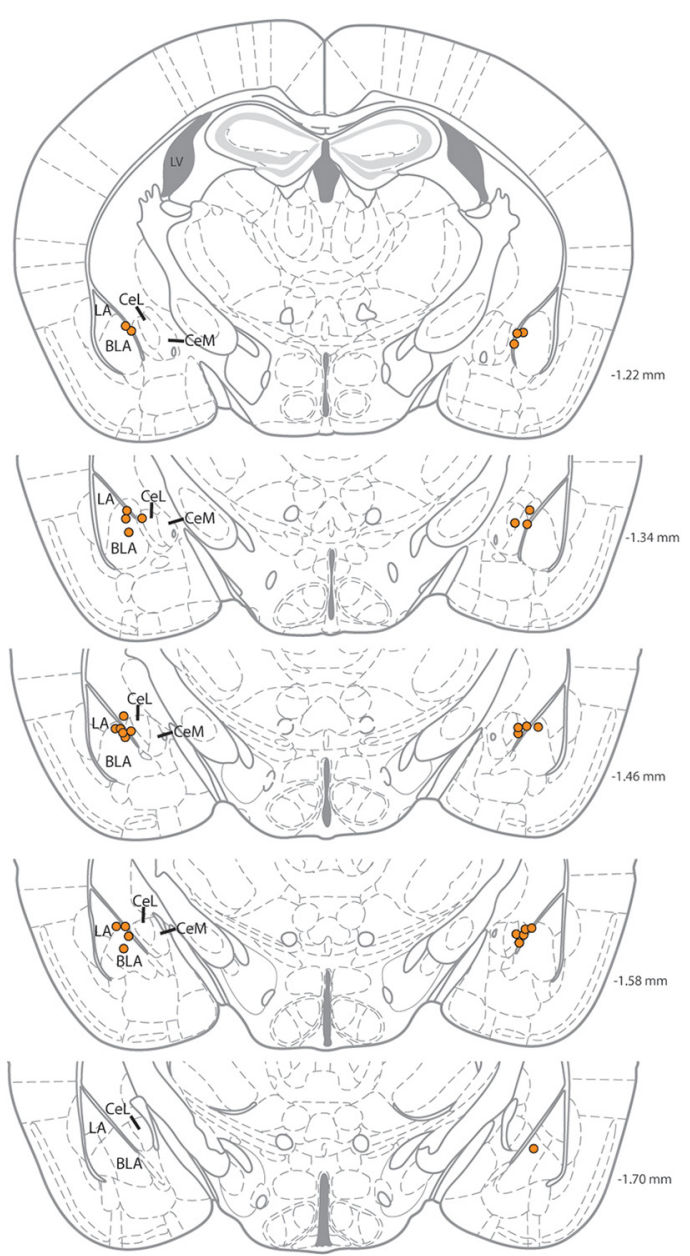
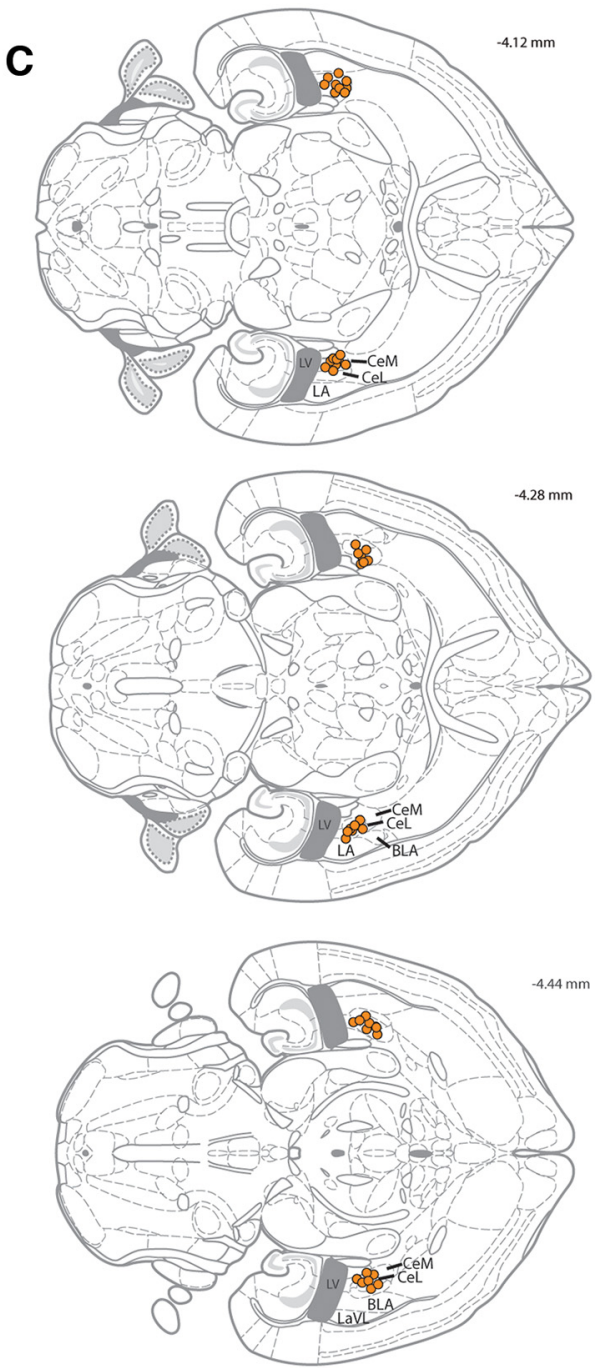

Figure 2. Histological confirmation of CBL amygdala cannulation. $A$, Representative cannula placement and the diffusion pattern of BODIPY-tagged muscimol (orange; equivalent volume and rate of experimental solutions) in the left hemisphere of coronally sectioned $(100 \mu \mathrm{m})$ tissue stained with DAPI (blue) at $4 \times$ magnification. Although some backflow can be observed along the cannula tract, the diffusion pattern indicates that all subnuclei of the CeA [only the lateral CeA (CeL) and medial CeA (CeM) are labeled in the image], lateral nucleus (LA), and basolateral (BLA) nucleus of the amygdala were affected, while surrounding areas such as the dorsal endopiriform claustrum (DeN) and ventral endopiriform claustrum (VeN) were spared. B, C, Schematic illustration (as adapted from the study by Franklin and Paxinos, 2007) of the cannula placement and diffusion patterns observed across all mice that received (BL amygdala infusions. Orange circles indicate the centroid of diffusion observed in BODIPY-tagged muscimol. B, Coronal sections. Numbers indicate posterior distance from bregma. $\boldsymbol{C}$, Horizontal sections. Numbers indicate ventral distance from skull. LV, lateral ventricle.

bulb. We implanted mice with four cannulae targeting the left and right LC and the left and right CBL amygdala. Each mouse received five baseline odor presentations, followed by a bilateral infusion of either muscimol or vehicle into the LC and a $20 \mathrm{~min}$ pause to allow diffusion, followed by five more odor trials, which were followed by a bilateral infusion of muscimol into the CBL amygdala and a 20 min pause, followed by five more odor presentations (Fig. 3). As above, at the conclusion of the experiment 
all four cannulae were infused with BODIPY-tagged muscimol to confirm infusion targeting, and subjects with any mistargeted cannulae were dropped. Focal inactivation of the LC is challenging, but modest cannula misplacements produced respiratory changes indicating that drug infusion affected the neighboring parabrachial nucleus, thus giving us a functional indicator of mistargeted drug spread. All successful infusions likely inactivated both the LC and Barrington's nucleus, a neighboring structure involved in micturition that has no known projections to the olfactory system or amygdala. In a total of 7 of 19 mice (totaling 298 glomeruli from 4 LC muscimol-infused animals and 3 LC vehicle-infused animals) successfully completed the procedure with correctly placed cannulae and no respiratory changes (Fig. 4).

A $2 \times 3$ ANOVA with LC infusate as a between-subjects factor (muscimol vs vehicle) and experiment stage as a within-subjects factor revealed a significant LC infusate $\times$ experiment stage interaction, as hypothesized $\left(F_{(1,296)}=106.822, p<0.001\right)$. After the initial infusion into the LC, there were no significant differences in odor-evoked glomerular PG cell activity between muscimol and vehicle infusions $\left(t_{(296)}=2.871\right.$; adjusted $\left.p=0.174\right)$, suggesting that there was little spontaneous norepinephrine (NE) release in the olfactory bulbs in these anesthetized mice. As shown in Figure 3, $A, C, E, G$, and $H$, muscimol infusion into the $\mathrm{CBL}$ amygdala following vehicle infusion into the $\mathrm{LC}$ produced a large decrease in odor-evoked PG cell activity $\left(t_{(106)}=-12.609\right.$; adjusted $p<0.001$ ), replicating the previous result (Fig. $1 G-I$ ). However, muscimol infusion into the CBL amygdala after LC inactivation had no significant effect on odor-evoked activity (Fig. $3 B, D, F-H ; t_{(190)}=-2.056$; adjusted $p>1$ ). These data demonstrate that LC function is necessary for CBL amygdala inactivation to influence PG cells in the olfactory bulb.

\section{Local blockade of noradrenergic signaling in the olfactory bulb prevents the effect of CBL amygdala inactivation on PG cells}

Though the LC is the only noradrenergic projection to the olfactory bulb, it also projects to other regions that, in turn, project to the olfactory bulb using other transmitters, including the horizontal limb of the diagonal band of Broca (cholinergic projections to the bulb) and the piriform cortex and anterior olfactory nucleus (glutamatergic projections to the bulb). Merely inactivating the LC therefore does not rule out the possibility that its effects on the bulb could be mediated indirectly. To confirm that CBL amygdala inactivation affects PG cell activity through direct noradrenergic signaling, we tested whether the local application of the broad-spectrum noradrenergic receptor antagonist labetalol to the olfactory bulb could prevent this effect. In these experiments, the initial surgery included implantation of bilateral cannulae targeting CBL amygdala and the removal of the skull and dura mater overlying the olfactory bulbs to allow direct application of drug to the olfactory bulb. In seven mice, we observed odorevoked PG cell activity during five baseline odorant presentations; then directly applied either vehicle or $13.7 \mathrm{~mm}$ labetalol to the olfactory bulb superfusate and waited $5 \mathrm{~min}$ to permit diffusion; delivered five more odorant presentations, infused muscimol into the CBL amygdala, and waited $20 \mathrm{~min}$; then delivered five more odorant presentations. As before, cannula position was verified histologically using a postexperiment infusion of fluorescent muscimol (Fig. 2).

A $2 \times 3$ ANOVA with olfactory bulb drug as a betweensubjects factor (labetalol vs vehicle) and experiment stage as a within-subjects factor revealed a significant infusate $\times$ experiment stage interaction, as hypothesized $\left(F_{(2,596)}=11.799, p<\right.$ 0.001 ; based on 300 glomeruli from seven mice). Consistent with the previous experiment showing that LC inactivation alone had no effect in the olfactory bulb (Fig. $3 B, D, F-H$ ), labetalol application (Fig. 5B,D, $F, G$ ) caused no significant difference compared with preinfusion baseline $\left(t_{(147)}=-1.744\right.$; adjusted $p=0.664)$ or vehicle control $\left(t_{(298)}=2.715\right.$; adjusted $\left.p=0.056\right)$. Vehicle application (Fig. $5 A, C, E, G$ ) also had no significant effect $\left(t_{(151)}=2.382\right.$; adjusted $\left.p=0.144\right)$ compared with baseline. After vehicle application to the olfactory bulb, CBL amygdala inactivation (Fig. $5 A, C, E, G, H$ ) evoked a significant reduction in average odor-evoked PG cell activity as in previous experiments $\left(t_{(151)}=\right.$ 8.794 , adjusted $p<0.001$ compared with prebulbar application baseline; $t_{(151)}=8.479$, adjusted $p<0.001$ compared with preinfusion baseline). However, after intrabulbar blockade of $\alpha$ - and $\beta$-type adrenergic receptors with labetalol (Fig. $5 B, D, F-H$ ), the inactivation of CBL amygdala had no effect on odor-evoked PG cell activity, which was not significantly different from its preamygdala infusion baseline $\left(t_{(147)}=1.974\right.$; adjusted $\left.p=0.400\right)$ or its prelabetalol baseline $\left(t_{(147)}=0.737\right.$; adjusted $\left.p>1\right)$ but was very different from its vehicle control $\left(t_{(298)}=4.005\right.$; adjusted $\left.p<0.001\right)$. Together with the previous experiments, these results confirm that CBL amygdala inactivation influences PG cell activity by inducing $\mathrm{NE}$ release from LC projections to the olfactory bulb.

\section{CBL amygdala inactivation preferentially enhances the weakest odor-evoked OSN outputs}

CBL amygdala-driven noradrenergic modulation of PG interneurons demonstrates that these regions can strongly influence early sensory processing, but its implications for odor representations and sensory gating are difficult to interpret. NE release can have complex effects on neural circuits, including directly altering neuronal excitability and presynaptically modulating the release of GABA from interneurons (Nai et al., 2009; Salgado et al., 2012; McGann, 2013; Nakamura et al., 2013; Pignatelli et al., 2013). Moreover, one of the major functions of PG cells is to presynaptically inhibit the synaptic output of OSNs (AroniadouAnderjaska et al., 2000; McGann et al., 2005; Murphy et al., 2005; Wachowiak et al., 2005), thus feeding back onto their own inputs. To explore the potentially diverse effects of CBL amygdala inactivation, we pooled data from 16 mice that received muscimol into the CBL amygdala across the three experimental cohorts from Figures 1, 3, and 5. While CBL amygdala inactivation reduced odor-evoked PG responses on average (Figs. $1 C, 3 H, 5 G$ ), Figure $6 \mathrm{~A}$ shows that the odor-evoked activity of PG cells in some glomeruli was greatly reduced while in a minority of glomeruli it was enhanced. ANOVA revealed that the magnitude of the odorevoked PG cell response before drug infusion was a significant factor in the size of the effect of amygdalar inactivation (one-way ANOVA: $\left.F_{(2,636)}=7.24, p<0.001\right)$, with the glomeruli that exhibited the smallest odor-evoked responses at baseline (operationally defined as the bottom third of the baseline response amplitudes) showing a significantly smaller (proportional) reduction on average than glomeruli in the middle $\left(t_{(424)}=3.092\right.$, adjusted $\left.p=0.006\right)$ and top $\left(t_{(424)}=3.671\right.$, adjusted $p<0.001$ ) thirds of the distribution (Fig. $6 B$ ). Please note that while the glomeruli in the bottom third of odor responses by definition exhibited a lower SNR than the others, the average single-trial SNR for the bottom third of glomeruli was nonetheless $64 \pm 5$ with a mean baseline odor-evoked response of $2.8 \%$ and a mean post-drug response of $2.4 \%$, demonstrating that 
A
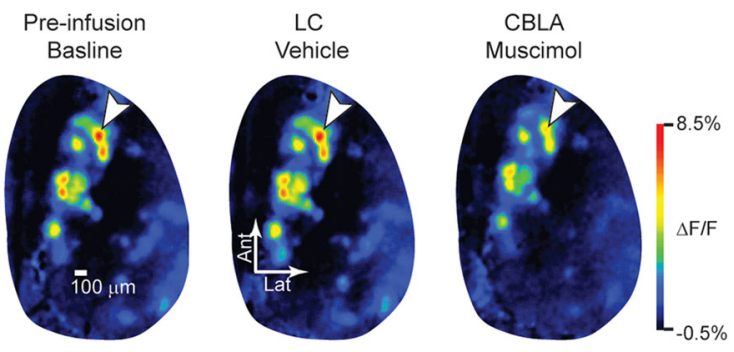

C
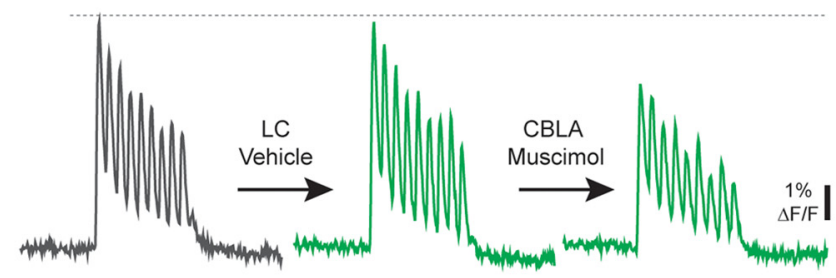

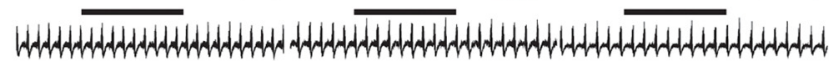

B

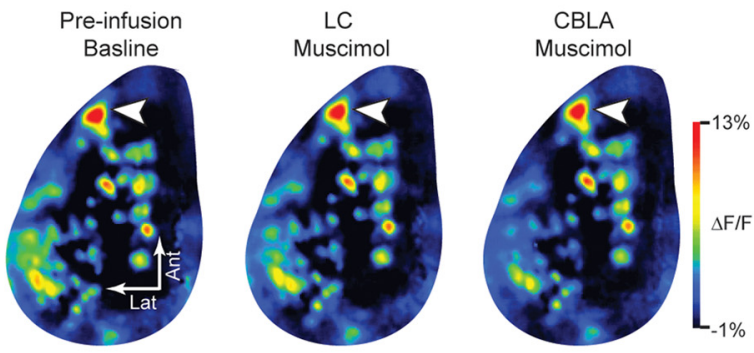

D

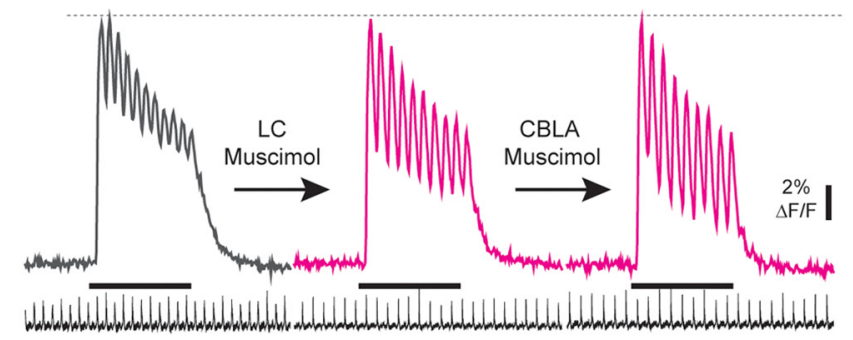

E

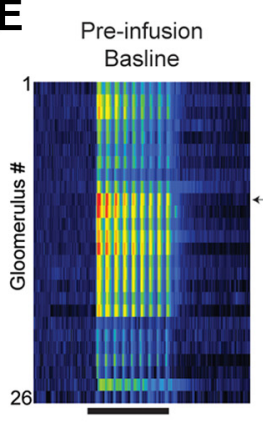

CBLA

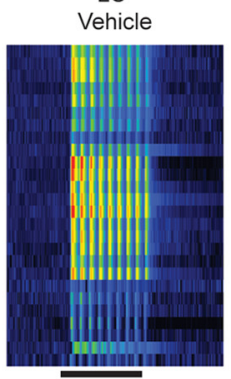

Muscimol

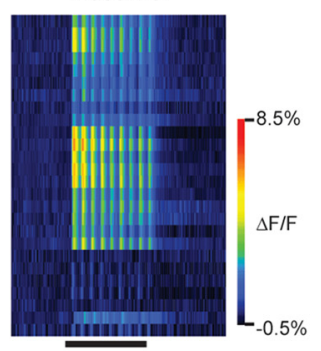

$\mathbf{F}$

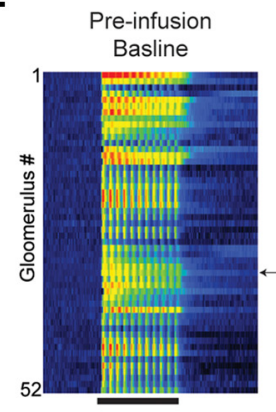

LC

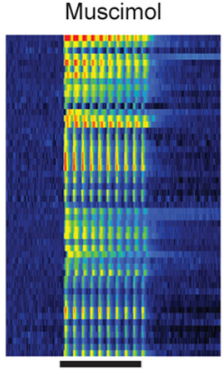

CBLA

Muscimo

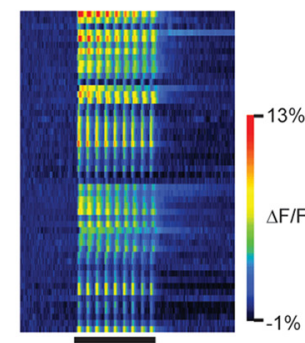

G

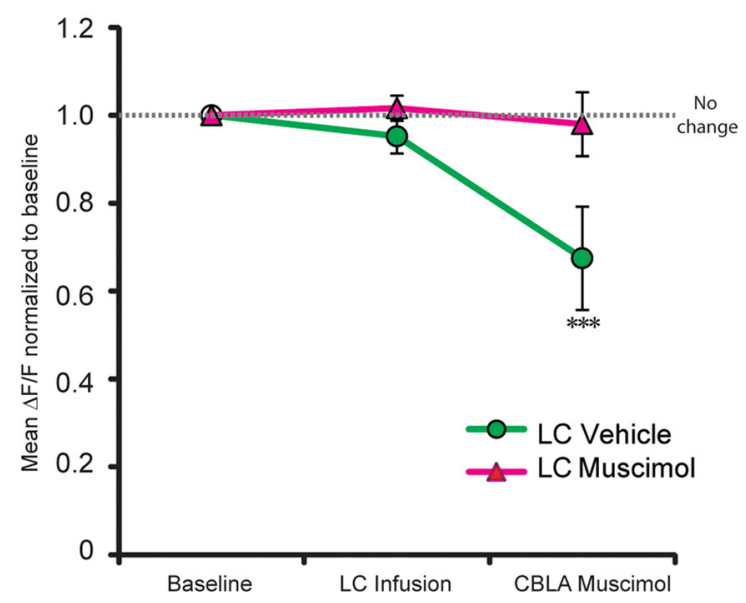

H

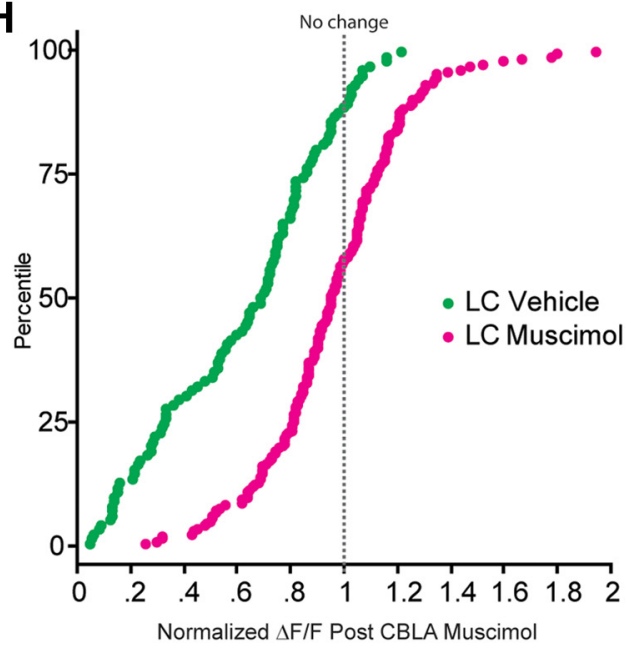

Figure 3. Inactivation of the locus coeruleus prevents the effect of CBL amygdala inactivation on PG cells. Transgenic mice expressing GCaMP6f in PG cells were each implanted with four cannulae, targeting the left and right $L C$ and left and right $C B L$ amygdala (CBLA). $A, B$, Pseudocolored activity maps showing the change in fluorescence of the olfactory bulb during the first inhalation of odorant before any infusion (left), after $L C$ infusion (middle) of vehicle $(\boldsymbol{A})$ or muscimol ( $\boldsymbol{B})$, and after subsequent $C B L$ amygdala infusion of muscimol (right). $\boldsymbol{C}, \boldsymbol{D}$, Traces indicating the change in fluorescence over time from the glomeruli indicated by arrows in $\boldsymbol{A}$ and $\boldsymbol{B}$ during odor presentations before any infusion (gray trace), following $\mathrm{L} C$ infusion of vehicle $(\boldsymbol{C}$, green trace) or muscimol ( $\boldsymbol{D}$, red trace), and after subsequent (BL amygdala infusion of muscimol (rightmost traces). Black bars indicate the delivery of odorant for $6 \mathrm{~s}$. Small black traces indicate respiration frequency, with upticks reflecting inhalation. $\boldsymbol{E}, \boldsymbol{F}$, Pseudocolored heat maps depicting the change in fluorescence in all responsive glomeruli (along the ordinate) over time (on the abscissa) before any infusions (left), after LC vehicle $(\boldsymbol{E})$ or muscimol $(\boldsymbol{F})$ infusion, and following (BL amygdala infusion of muscimol for the example shown in $\boldsymbol{A}$ and $\boldsymbol{B}$. The arrows denote which line of (Figure legend continues.) 
these odor-evoked signals were readily detectable in single trials even within the bottom third of the distribution.

The odor-evoked activity observed in glomerular populations of PG cells reflects the summation of multiple factors, including the direct excitation of some PG cells by OSNs and indirect excitation of PG cells by other OSN-driven neurons in the glomerular circuit (Shao et al., 2009), both of which are influenced by a presynaptic modulation of OSN synaptic output (McGann, 2013). However, previous studies have implicated noradrenergic signaling in the gating of weak sensory input (Waterhouse et al., 1988; Adler et al., 1994; Jiang et al., 1996; Ciombor et al., 1999; Bouret and Sara, 2002; Devilbiss et al., 2012; García-Ramírez et al., 2014), suggesting that the release of NE in the olfactory bulb induced by CBL amygdala inactivation might be preferentially boosting the smallest odor-evoked inputs to the bulb from the OSNs. Should this boosting of weak OSN output occur in combination with a global decrease in PG excitability, it would be reflected in Figure 6 as a smaller reduction of PG cell activity for weakly activated glomeruli, as observed. We thus tested the hypothesis that CBL amygdala inactivation selectively increased odor-evoked OSN output in weakly activated glomeruli.

Odor-evoked OSN synaptic output was visualized in vivo in gene-targeted mice expressing the fluorescent exocytosis indicator $\mathrm{spH}$ from the promoter for OMP. In these OMP-spH mice, populations of axons from mature OSNs are visible innervating all olfactory bulb glomeruli (Fig. 7A) and linearly indicate cumulative glutamate release from OSNs during each odor presentation (Bozza et al., 2004; Wachowiak et al., 2005). OMP-spH mice were implanted with intra-amygdalar cannulae, and odorevoked OSN output was measured before and after the intra-CBL amygdala infusion of either muscimol or vehicle control, as above. As shown in Figure 7, $C$ and $G-I$, muscimol infusion into the amygdala modestly but significantly increased the overall average odor-evoked OSN output $\left(t_{(218)}=2.438\right.$, adjusted $p=0.03$ based on 219 glomeruli in seven mice). More importantly, this effect was significantly different across the population (one-way ANOVA, $F_{2,216}=15.77, p<0.001$ ), with the net change almost entirely attributable to a $36 \pm 10 \%$ increase in the response of the most weakly activated third of glomeruli (Fig. 7B; one-sample $t$ test compared with no change: $t_{(73)}=3.70$; adjusted $p=0.001$ ), with no significant change in the middle third of the distribution $\left(t_{(73)}=-1.32\right.$; adjusted $\left.p=0.570\right)$ and a slight but significant decrease in the most strongly activated third $\left(t_{(73)}=-2.75\right.$; adjusted $p=0.021)$. As shown in Figure $7, H$ and $I$, within the most weakly activated third of glomeruli, there was a general trend toward the most weakly activated glomeruli showing the largest proportional increases, but even glomeruli with very similar initial responses in the same mouse (Fig. $7 \mathrm{H}$, I, pink and magenta; note that glomerulus 3 is from the olfactory bulb on the other side of the same mouse) could exhibit increases of quite different sizes. Vehicle-infused mice (Fig. $7 D-F$ ) showed no significant

(Figure legend continued.) each heat map corresponds to the glomeruli illustrated in $\boldsymbol{C}$ and $\boldsymbol{D}$. $\mathbf{G}$, Summary data across mice showing that inactivating $L C$ prevented the subsequent $C B L$ amygdala inactivation from altering PG activity (red triangles), whereas infusing vehicle into the $\mathrm{LC}$ before $\mathrm{CBL}$ amygdala inactivation produced a significant decrease in PG activity (green circles) in accordance with the data shown in Figure 1. Notably, no change in odor-evoked activity was observed following $\mathrm{LC}$ infusion of either vehicle or muscimol. Error bars represent the SEM. ${ }^{* * *}$ A statistically significant difference at $p<0.001$. $\boldsymbol{H}$, Cumulative frequency histogram illustrating the distribution of changes in odor-evoked activity after CBL amygdala inactivation across all glomeruli normalized to preinfusion baseline for mice that had received an $\mathrm{LC}$ infusion of either vehicle (green points) or muscimol (red points). Lat, Lateral; Ant, anterior.
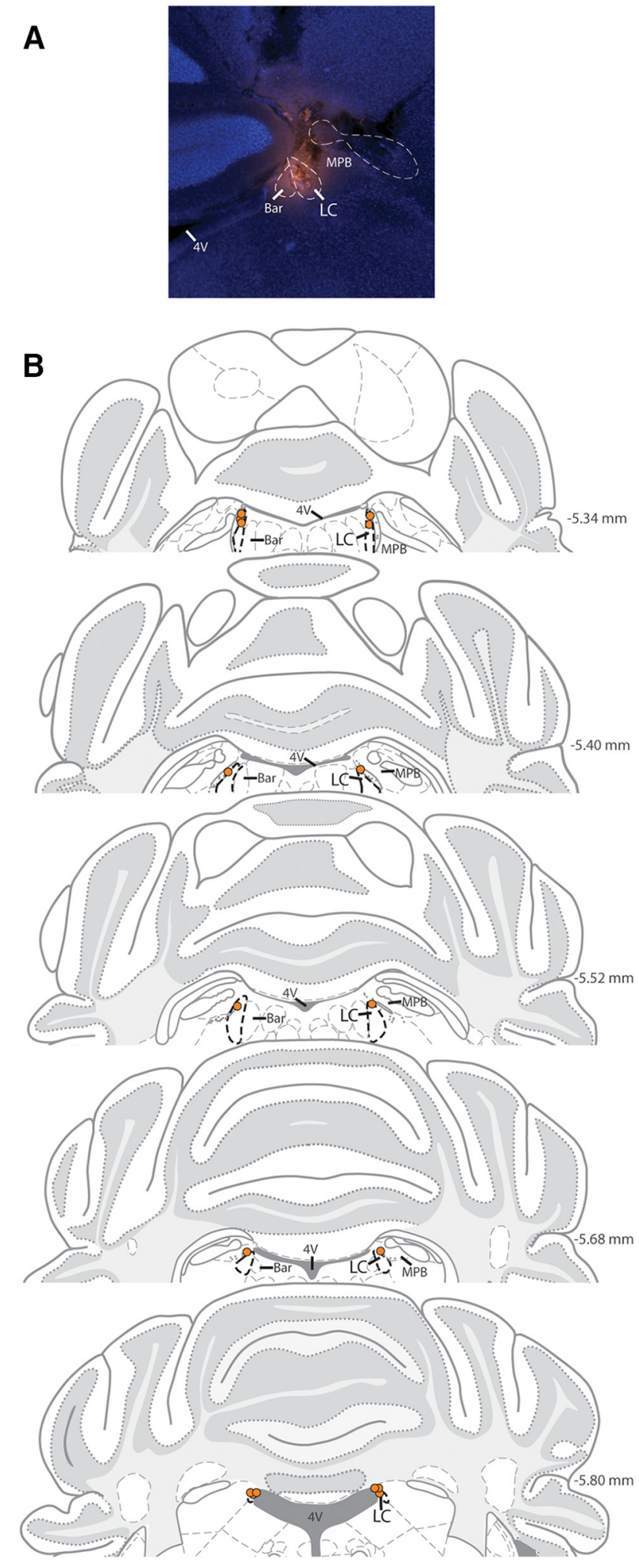

Figure 4. Histological confirmation of $L C$ cannulation. $A$, Representative cannula placement and diffusion pattern of BODIPY-tagged muscimol (orange; equivalent volume and rate of experimental solutions) in the right hemisphere of coronally sectioned (100 $\mu \mathrm{m})$ tissue stained with DAPI (blue) at $4 \times$ magnification. The small volume and rate of infusion minimized backflow along the cannula tract and diffusion into surrounding structures, although Barrington's nucleus (Bar) was likely affected, as shown here. B, Coronal illustration (as adapted, with permission, from Franklin and Paxinos, 2007) of infusion locations across animals. Orange circles indicate the centroid of BODIPY-tagged muscimol diffusion. Numbers indicate posterior distance from bregma. MPB, Medial parabrachial nucleus; $4 \mathrm{~V}$, fourth ventricle. 
A
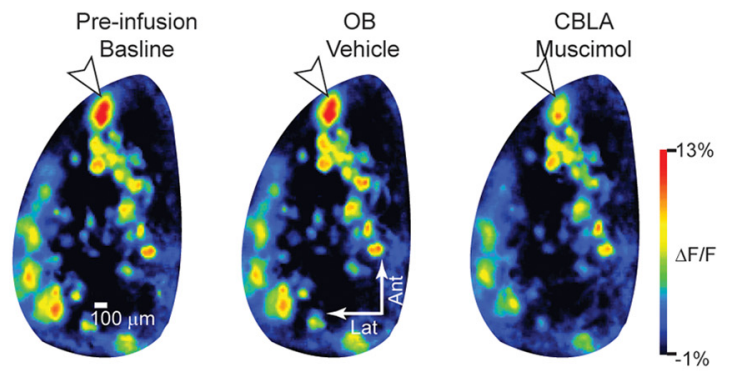

B

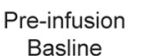

$\mathrm{OB}$

Labetalol

CBLA
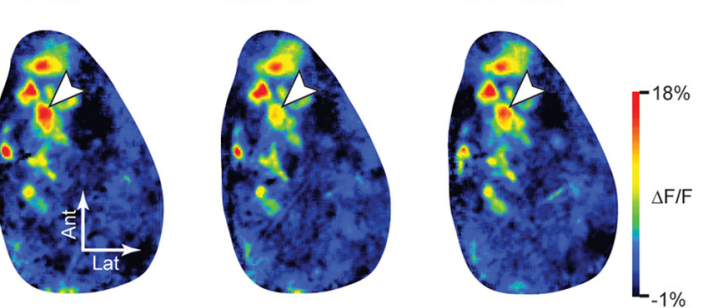

C

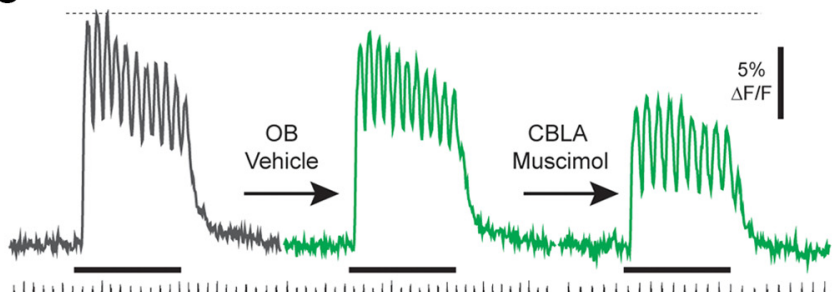

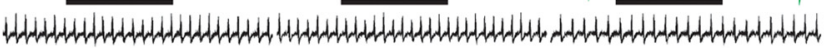

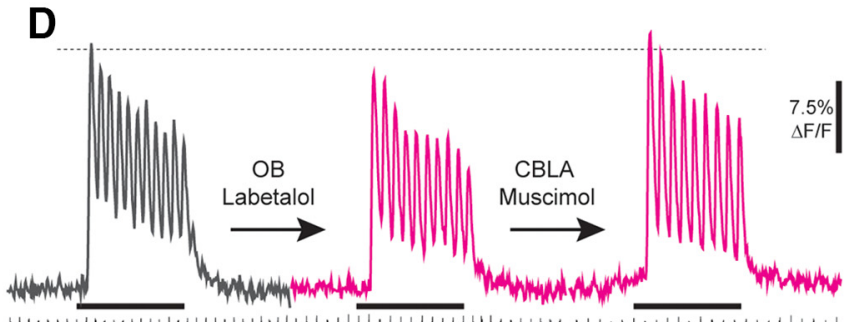

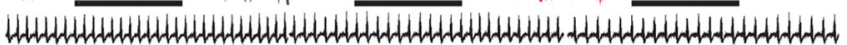

E
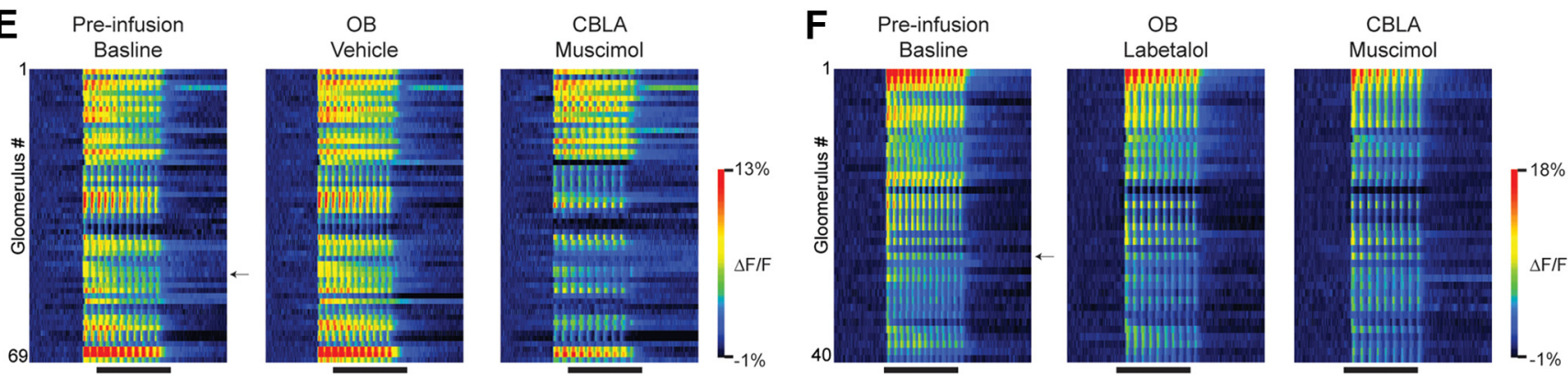

G

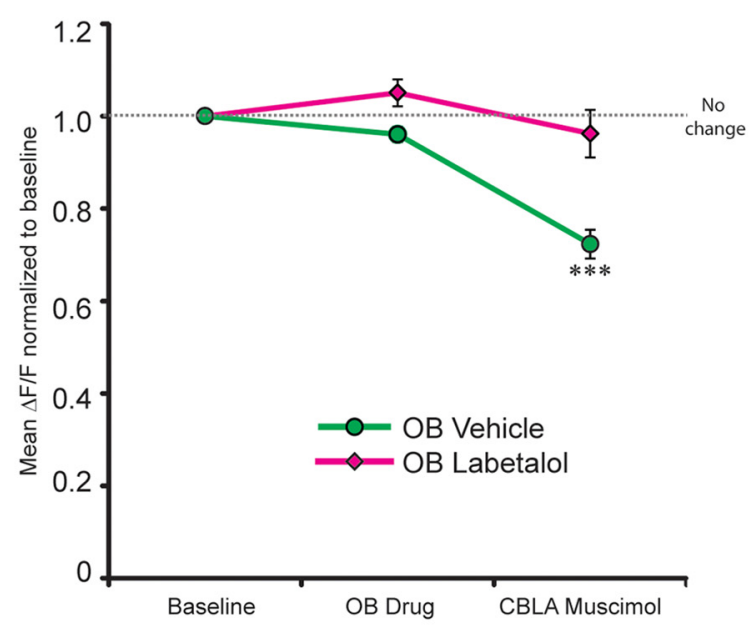

H

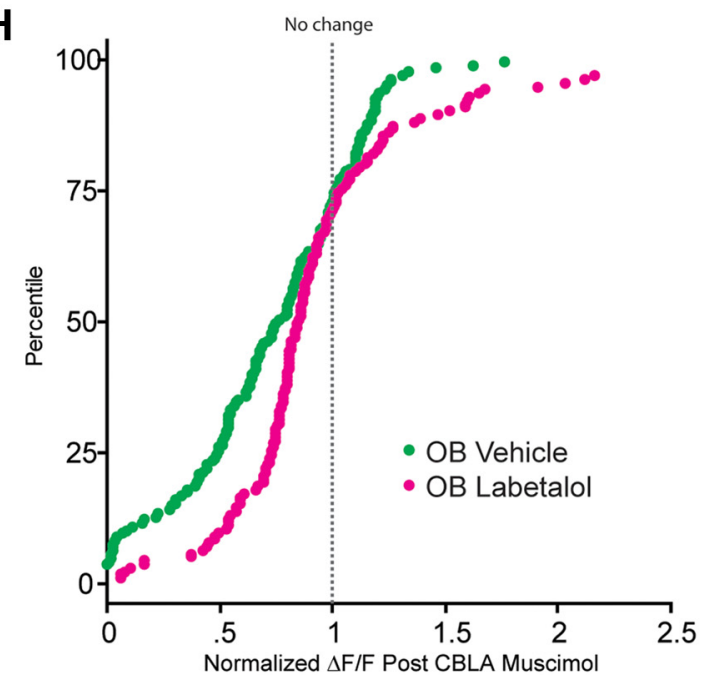

Figure 5. Local blockade of noradrenergic signaling in the olfactory bulb prevents the effect of CBL amygdala inactivation on PG cells. Bilateral cannulae targeting the CBL amygdala (CBLA) were implanted, and the skull and dura mater overlying the olfactory bulb were removed in PG-GCaMP6f mice. $A, B$, Pseudocolored activity maps showing the change in fluorescence of the olfactory bulb (OB) during the first inhalation of odorant in preinfusion baseline trials (left) after vehicle $(\boldsymbol{A})$ or the broad-spectrum noradrenergic antagonist labetalol ( $\boldsymbol{B}$ ) was applied to the 0 B superfusate (middle) and after subsequent $C B L$ amygdala infusion of muscimol (right). $\boldsymbol{C}, \boldsymbol{D}$, Traces indicating the change in fluorescence over time from the glomeruli indicated by arrows in $\boldsymbol{A}$ and $\boldsymbol{B}$ during odor presentations on baseline trials (gray trace), following $0 B$ application of vehicle ( $\boldsymbol{C}$, green trace) or labetalol ( $\boldsymbol{D}$, red trace), and after subsequent (BL amygdala infusion of muscimol (rightmost trace). Black bars indicate delivery of odorant for $6 \mathrm{~s}$. Small black traces indicate respiration frequency, with upticks reflecting inhalation. $\boldsymbol{E}, \boldsymbol{F}$, Pseudocolored heat maps depicting the change in fluorescence in all responsive glomeruli (along the ordinate) over time (on the abscissa) during baseline trials (left), after OB application of vehicle (E) or labetalol (F), and following (BL amygdala infusion of muscimol for the example shown in $\boldsymbol{A}$ and $\boldsymbol{B}$. The arrows denote which line of each heat map corresponds to the glomeruli illustrated in $\boldsymbol{C}$ and $\boldsymbol{D}$. $\boldsymbol{G}$, Summary data showing the mean change in odor-evoked responses across all glomeruli. Replicating the effect of $\mathrm{LC}$ inactivation, labetalol applied to the OB prevented the subsequent (BL amygdala (Figure legend continues.) 
A

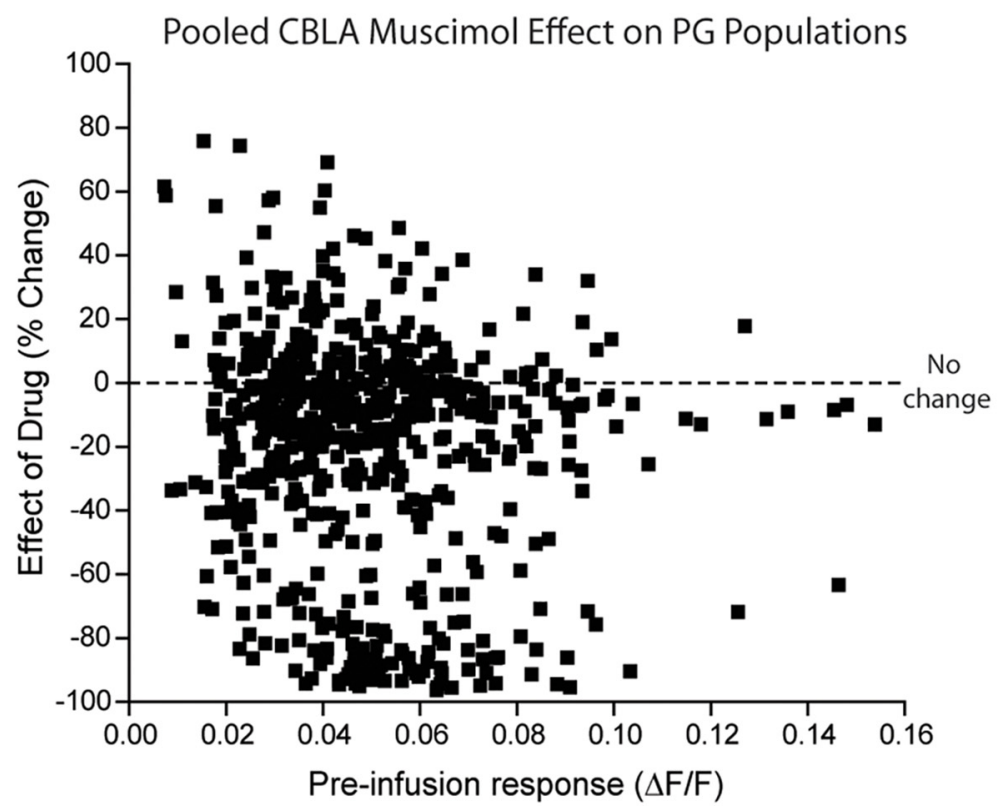

B

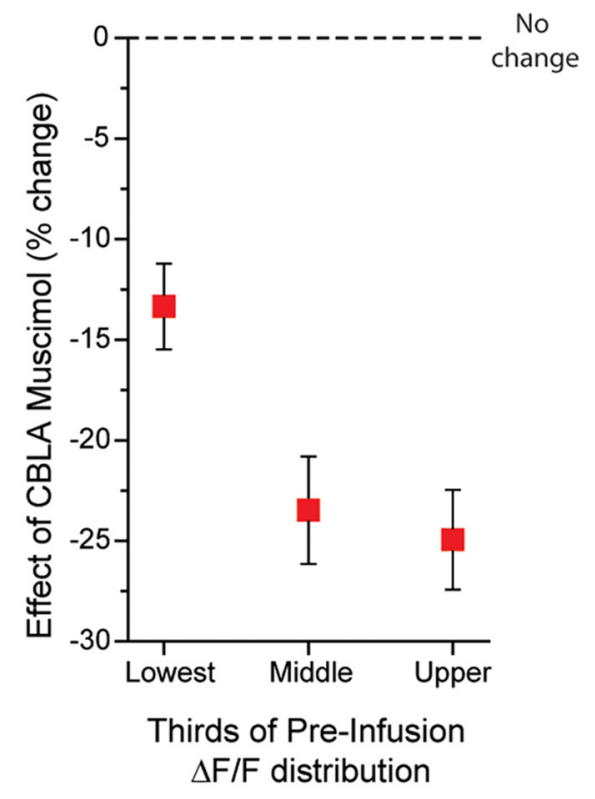

Figure 6. CBL amygdala inactivation differentially affects PG cell activity depending on baseline odor-evoked responding. We pooled data from 16 mice across three experimental cohorts that received muscimol infused into the CBL amygdala. $\boldsymbol{A}$, Scatter plot of the change in odor-evoked PG cell activity in olfactory bulb glomeruli following CBL amygdala inactivation against preinfusion odor-evoked response amplitude. Each circle represents one glomerulus. Although CBL amygdala inactivation reduced odor-evoked glomerular responses on average, the effect was very heterogeneous and included some glomeruli that showed an increased response. $\boldsymbol{B}$, Summary plot of the mean effect of CBL amygdala inactivation for glomeruli in the bottom, middle, and top thirds of the distribution of preinfusion responses. CBL amygdala inactivation suppressed PG cell activity less in glomeruli that exhibited the weakest odor-evoked response before the CBL amygdala infusion of muscimol.

effect $\left(99 \pm 1 \%\right.$ of control overall; $t_{(166)}=-0.577$; adjusted $p>1$; based on 166 glomeruli in 6 mice). These data confirm that one consequence of CBL amygdala inactivation is selective enhancement of weak sensory signals from the olfactory nerve to the brain.

\section{Discussion}

The present study demonstrated that pharmacological blockade of activity in the central, basolateral, and lateral nuclei of the amygdala changed the response of the early olfactory system to odors, including preferentially enhancing the synaptic output of weakly activated olfactory sensory neuron populations and suppressing the activity of GABAergic periglomerular interneurons in most glomeruli. This influence was mediated through NE released in the olfactory bulb from noradrenergic afferents coming from the LC. The finding that amygdala and LC activity can shape sensory processing as early as the primary sensory input to the brain suggests that the state of these regions influences which sensory signals are selected for neural processing.

(Figure legend continued.) inactivation from altering PG cell activity (red diamonds), whereas $O B$ application of vehicle before $C B L$ amygdala inactivation produced a significant decrease in PG activity (green circles) in accordance with the data shown in Figure 1. $\boldsymbol{H}$, Cumulative frequency histogram illustrating the distribution of changes in odor-evoked activity after CBL amygdala inactivation across all glomeruli normalized to preinfusion baseline for mice that had received intrabulbar application of either vehicle (green points) or labetalol (red points). Together with the previous experiments, these results confirm that CBL amygdala inactivation influences PG cell activity by inducing norepinephrine release from LC projections to the olfactory bulb. Lat, Lateral; Ant, anterior.
Circuit-level mechanisms

How did decreased activity in the CBL amygdala cause excitation of the LC in the present experiments? There are extensive projections from the CeA to the LC (Van Bockstaele et al., 1998, 1999; Retson and Van Bockstaele, 2013; Schwarz et al., 2015). These CeA to LC projections include both symmetric (presumed inhibitory) and asymmetric (presumed excitatory) synapses when viewed using electron microscopy and frequently coexpress neuropeptides like corticotropin-releasing factor (CRF) and dynorphin that can also have inhibitory effects (Valentino et al., 1992; Van Bockstaele et al., 1998; Van Bockstaele et al., 1999; Tjoumakaris et al., 2003; Reyes et al., 2008; Retson and Van Bockstaele, 2013). In our experiments, pharmacological inactivation of the central nucleus (and its inputs from basolateral and lateral nuclei) thus presumably evoked NE release by disinhibiting the LC. As illustrated in Figure 8, the disinhibition of LC led to a suppression of PG cell activity (Fig. 6) and increased OSN output in some glomeruli (Fig. 7). However, it is important to note that these experiments were performed in experimentally naive animals under pentobarbital anesthesia, so the efficacy of inhibitory synapses between CeA and LC was likely enhanced by the anesthesia, and the spontaneous activity of LC was doubtless suppressed compared with the awake state. Nonetheless, this approach proves that CBL amygdala is capable of influencing sensory gating through its connectivity to the LC. Follow-up experiments using attentional tasks, fear conditioning, or stress to explicitly manipulate the state of the amygdala-LC circuit will be necessary to explore the various ways that these regions can influence sensory processing, including in circumstances where amygdala activity excites the LC. Such tasks will also provide the opportunity to explore the broader network interacting with the CBL 
A

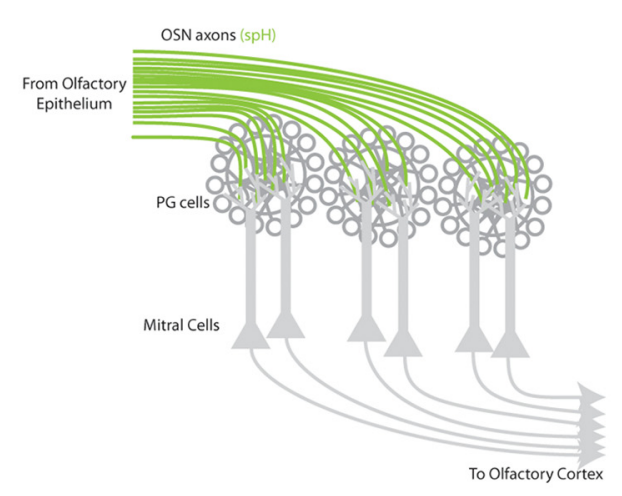

B
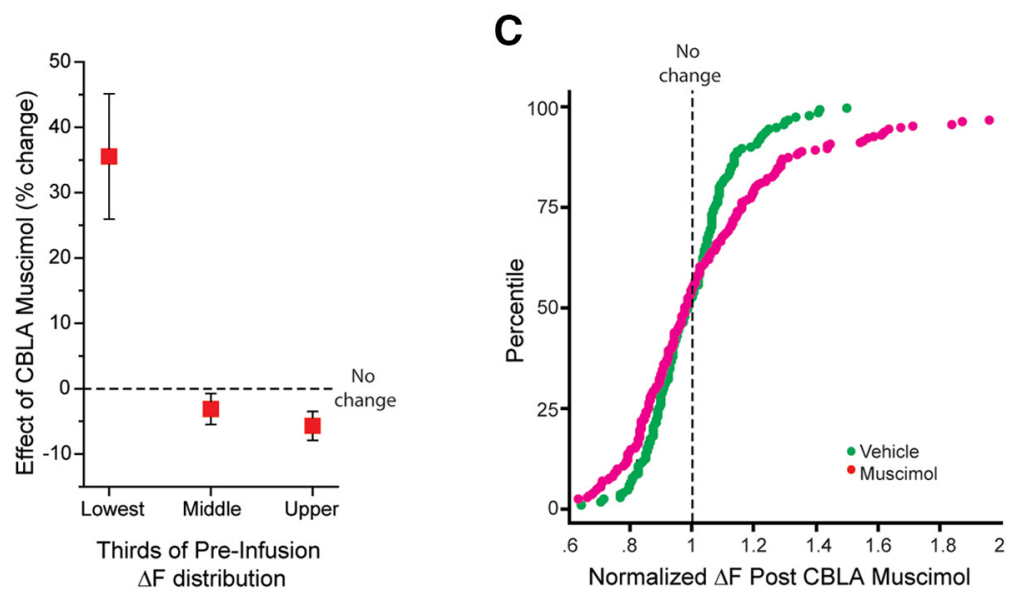

D
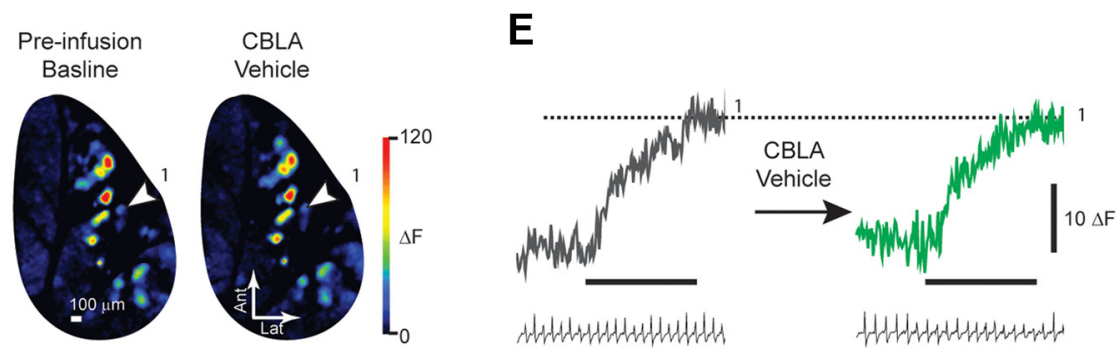

$\mathbf{F}$

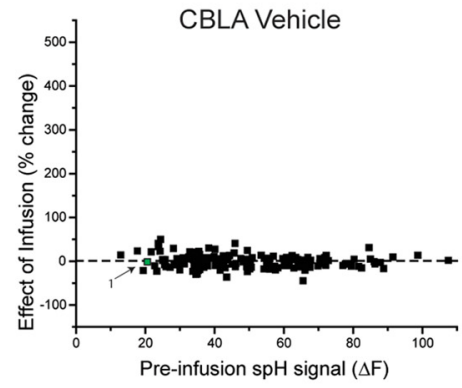

G
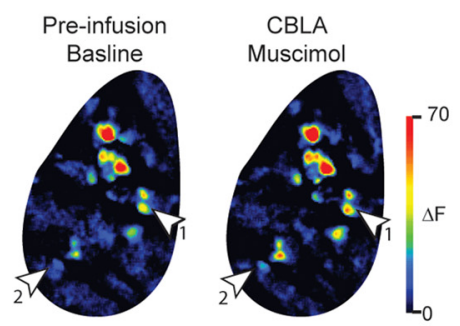

H

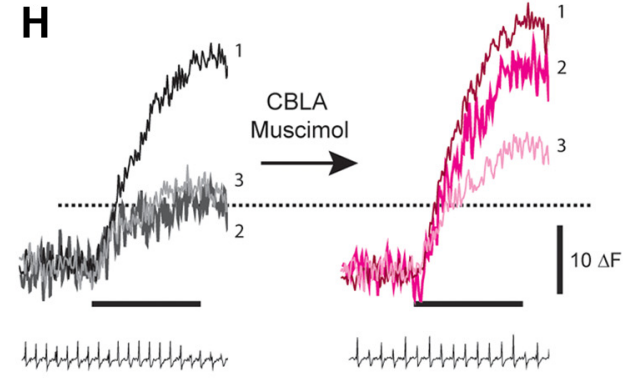

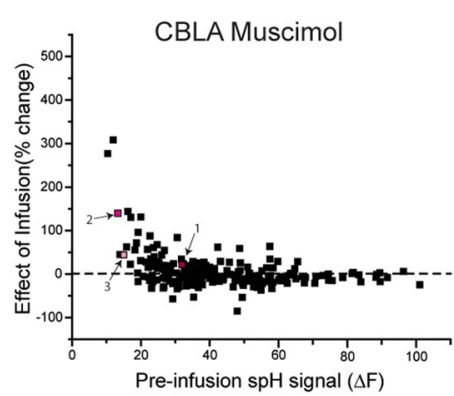

Figure 7. CBL amygdala inactivation preferentially enhances the weakest odor-evoked OSN outputs. Odor-evoked output of OSNs was visualized in gene-targeted mice expressing the fluorescent exocytosis indicator spH before and after CBL amygdala (CBLA) infusion of either vehicle or muscimol. $A$, Schematic illustration of the first stage of olfactory processing on the surface of the olfactory bulb with OSN axon terminals highlighted in green to indicate their expression of spH. B, Summary across mice showing the change in mean OSN output following CBL amygdala inactivation based on where each glomerulus fell in the distribution of preinfusion odor-evoked response amplitudes (i.e., lowest, middle, and top third of baseline odor-evoked responses). CBL amygdala inactivation selectively enhanced odor-evoked OSN output in glomeruli that exhibited the weakest odor-evoked responses at baseline. Error bars represent the SEM. C, Cumulative frequency histogram illustrating the distribution of changes in glomerular inputs normalized to baseline following (BL amygdala infusion of either vehicle (green points) or muscimol (red points). D, G, Pseudocolored activity maps showing the change in fluorescence of the olfactory bulb at the end of odorant presentation before and after CBL amygdala infusions of vehicle (D) or muscimol (G). $\boldsymbol{E}, \boldsymbol{H}$, Traces indicating the change in fluorescence over time from the glomeruli indicated by arrows in $\boldsymbol{D}$ and $\boldsymbol{G}$ during odor presentations before (gray trace) and following (BL amygdala infusion of vehicle $(\boldsymbol{E}$, green trace) or muscimol $(\boldsymbol{H}$, pink, magenta, and dark red traces). Black bars indicate the delivery of odorant for $6 \mathrm{~s}$. Small black traces indicate respiration frequency, with upticks reflecting inhalation. Glomeruli 1 and 2 refer to the location of the glomeruli in $\boldsymbol{G}$. Note that glomerulus 3 is from the other olfactory bulb of this mouse and so is not visible in $\mathbf{G}$; it was included for comparison because of its similar response size to glomerulus 2 at baseline but divergence after muscimol. $F, I$, Scatter plots of odor-evoked glomerular inputs following CBL amygdala infusion of either vehicle $(\boldsymbol{F})$ or muscimol $(\boldsymbol{I})$ as a function of preinfusion magnitude. Glomeruli illustrated in $\boldsymbol{H}$ are labeled. As seen with PG cell activity, CBL amygdala inactivation selectively influenced the response magnitude in glomeruli that were weakly driven by the odorant at baseline.

amygdala (Mouly and Di Scala, 2006), including other olfactory regions like piriform cortex (Sadrian and Wilson, 2015), polymodal cortical structures like perirhinal cortex and anterior cingulate cortex (Sripanidkulchai et al., 1984; Kealy and Commins, 2011), and regions involved in modulating amygdalar output like prefrontal cortex (Carmichael and Price, 1995; Murray and Wise, 2010).
Sensory input to the brain uses a local circuit motif that occurs almost identically in the olfactory, visual, and auditory systems, where glutamatergic sensory afferents reach the brain from the olfactory epithelium, retina, or cochlea, respectively, and their neurotransmitter release is regulated by presynaptic $\mathrm{GABA}_{\mathrm{B}}$ receptors activated by GABA release from local interneurons (Brenowitz et al., 1998; Chen and Regehr, 2003; McGann, 2013). All 

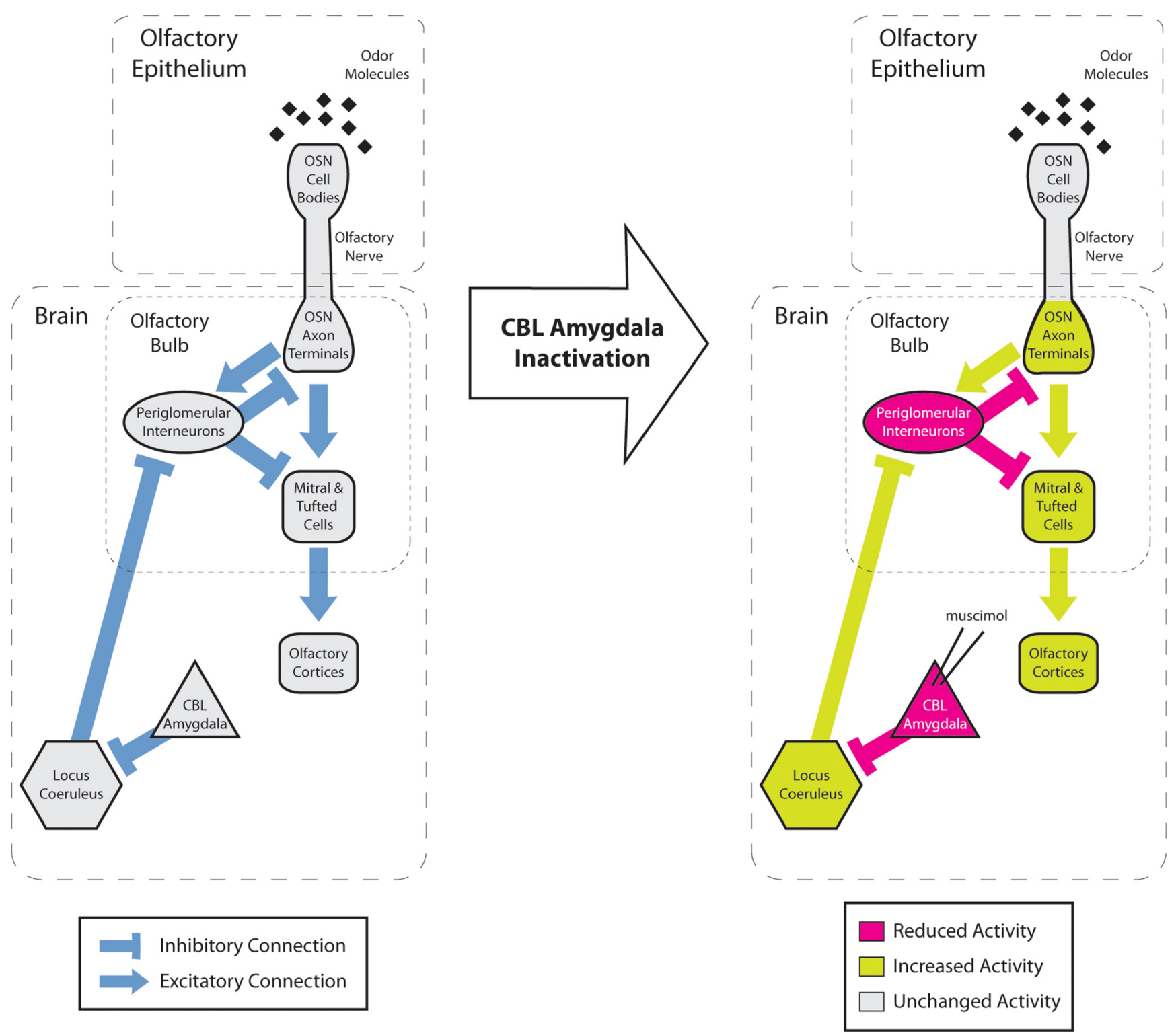

Figure 8. Schematic illustration of amygdala-locus coeruleus- olfactory bulb interactions. Diagram of a subset of interconnections within and between the olfactory system, amygdala, and locus coeruleus responsible for the data reported above. Left, OSNs located in the olfactory epithelium in the nose detect the odorant molecules and project their axons to the glomeruli of the olfactory bulb, where they release glutamate onto mitral and tufted cells (which project to the olfactory cortex) and onto local interneurons called PG cells. PG cells also receive noradrenergic input from the LC, which is in turn inhibited by activity in the CBL nuclei of the amygdala. PG cells release the inhibitory transmitter GABA onto OSN axon terminals (presynaptically inhibiting their transmitter release) and onto mitral and tufted cells. Right, Infusion of muscimol into the CBL amygdala silences local activity (decreased activity shown in red), which disinhibits the LC (increased activity shown in green), which inhibits PG cells (via norepinephrine release), disinhibiting weakly activated OSN axon terminals. The increased OSN output in the glomeruli is presumably reflected in stronger odor-evoked activity in mitral and tufted cells and thus the input to the olfactory cortices.

three regions receive noradrenergic input from the LC (Kromer and Moore, 1980a,b; McLean et al., 1989), suggesting that LCmediated shaping of the initial sensory input to the brain could be a general feature of sensory information processing. In the present data, we speculate that one consequence of NE suppressing most PG cell activity was decreased tonic presynaptic inhibition of OSN terminals (Pírez and Wachowiak, 2008), which in turn disproportionately boosted weak OSN outputs and evoked stronger PG cell activity in those glomeruli (Fig. 6). Interestingly, it has been proposed that this presynaptic inhibition might serve not only as a gate but as a temporal filter, potentially suppressing initial sensory responses to enable sustained responses (Brenowitz and Trussell, 2001) or temporally structuring neural activity to match phasic sensory dynamics (Wachowiak et al., 2005; Verhagen et al., 2007).
NE release in the olfactory bulb has been previously linked to decreases in GABA release in slice experiments (Nai et al., 2009) and has been shown to preferentially boost the responses of olfactory bulb mitral cells to weak OSN stimulations in vivo (Jiang et al., 1996). At the behavioral level, pharmacological activation of the olfactory bulb NE system evokes selectively improved olfactory performance at low odor concentrations (Escanilla et al., 2010). The present data are thus consistent with previous reports that NE release in the bulb opens the gate on weak olfactory sensory input to the brain.

We note that a previous study (Eckmeier and Shea, 2014) reported that LC stimulation-evoked release of NE in the bulb suppressed calcium signaling in OSN terminals, which potentially contradicts our Figure 7. However, their results may not be directly comparable to ours because they used $5 \mathrm{~Hz}$ electrical 
stimulation of the LC, which is likely to produce an artificially high concentration of NE in the bulb, which might activate different receptor populations (Nai et al., 2009). Furthermore, they used ketamine/xylazine anesthesia, which disrupts noradrenergic tone (Kubota et al., 1999) and directly interacts with NE receptors and $\mathrm{HCN}-1$ channels present in the OSNs and glomerular circuit (Fried et al., 2010; Nakashima et al., 2013). The present study used pentobarbital anesthesia, which enhances the efficacy of GABA at $\mathrm{GABA}_{\mathrm{A}}$ receptors (Steinbach and Akk, 2001), which are found throughout the olfactory bulb (though seemingly not on OSN terminals) but do not directly interact with NE receptors. Nonetheless, in our study the use of anesthetic doubtless puts the olfactory bulb circuit into an unnatural state that necessitates follow-up work in awake animals to determine the normal role of the LC $\rightarrow$ olfactory bulb circuit in olfactory coding.

\section{Relevance to olfactory information processing and amygdala-dependent learning}

A key role of sensory brain regions is the selection of sensory stimuli for neural processing by prioritizing stimuli based on the current behavioral or neuromodulatory state of the organism (Hurley et al., 2004; Salgado et al., 2016). This function can have many implementations, including selectively regulating neural responses to weak sensory stimuli, discriminating an ecologically important stimulus from background activity (Gaucher and Edeline, 2015), and adapting out static inputs in favor of dynamic ones. These selection processes use noradrenergic modulation of sensory regions in various ways, including both "opening the gate" for weak sensory inputs in some circumstances (Waterhouse et al., 1988, 1990; Jiang et al., 1996; Ciombor et al., 1999) and suppressing them in others (Manunta and Edeline, 1997; Zitnik et al., 2013). The present data extend our understanding of this system both outwardly, by demonstrating that even the synaptic output of primary sensory neurons can be influenced by LC and CBL amygdala activity (Fig. 7), and inwardly, by showing that the state of the amygdala can indirectly determine the gating of sensory input to the brain through its connections to LC. These findings dovetail with recent evidence that post-traumatic stress disorder (PTSD) patients undergoing aversive visual conditioning exhibit strong functional connectivity among the amygdala, locus coeruleus, and early visual processing areas like the thalamus and primary visual cortex (Morey et al., 2015).

Sensory gating deficits are a key biomarker for attention deficit hyperactivity disorder, schizophrenia, Tourette's syndrome, and affective disorders like depression, panic disorder, and PTSD (Light and Braff, 1999; Alsene and Bakshi, 2011; Sable et al., 2012; Oranje et al., 2013; Micoulaud-Franchi et al., 2015a,b), conditions that also include explicit sensory attention symptoms like hypervigilance and attentional bias (Felmingham et al., 2011; Felmingham et al., 2012; Hegerl and Hensch, 2014). These symptoms, some of which can be mimicked in neurotypical subjects by pharmacologically boosting NE release (Adler et al., 1994; Hammer et al., 2007), likely relate to dysfunctional activity in the LC (Bernard et al., 2011; Pietrzak et al., 2013; Morey et al., 2015). In animal models, increased LC activity promotes vigilance behavior (Aston-Jones et al., 1991, 1994; Rajkowski et al., 1994), but high tonic firing rates in $\mathrm{LC}$ are related to errors on tasks requiring focused attention on specific stimuli (Aston-Jones and Cohen, 2005). The current finding that LC-driven NE release can regulate sensory input to the brain provides a novel potential target for investigating sensory gating function and dysfunction.

One critical element of the current work is that it shows how differences in amygdala activity could have sensory consequences mediated by the LC (van Marle et al., 2009; Devilbiss et al., 2012; Chen et al., 2014; Ousdal et al., 2014). Amygdala output is strongly regulated by aversive experiences and by stress, which evoke the release of CRF from central amygdala into the LC (Van Bockstaele et al., 1998, 1999; Reyes et al., 2008). This stressinduced CRF release causes a wide range of sensory dysfunctions, including reduced thalamic and sensory cortical responses to stimuli (Devilbiss et al., 2012) and disrupted sensorimotor gating (Bakshi et al., 2012). The present data suggest that this may underlie a previous report showing that stress impairs olfactory discrimination via noradrenergic action in the olfactory bulb (Manella et al., 2013) and may illuminate recent findings that fear conditioning disproportionately enhances LC and sensory responses to highly emotional stimuli in PTSD patients (Morey et al., 2015).

Models of the biological underpinnings of fear learning prominently feature the CBL amygdala and $\mathrm{LC}$ as recipients of sensory information (Fanselow and Poulos, 2005; Johansen et al., 2011, 2014), rather than shapers of it. However, theories of associative learning have always included stimulus-specific parameters intended to capture the "associability" of a sensory cue (Rescorla and Wagner, 1972; Mackintosh, 1975; Pearce and Hall, 1980), which are usually characterized by the salience of the physical stimulus (e.g., loudness of a tone). This stimulus-specific associability has been proposed to be increased by learning itself (Mackintosh, 1975), and evidence is accumulating that the early olfactory system indeed exhibits sometimes profound plasticity during a variety of classically amygdala-dependent experimental tasks, including fear conditioning (Li et al., 2008; Fletcher, 2012; Åhs et al., 2013; Kass et al., 2013d; Krusemark et al., 2013; Dias and Ressler, 2014; Morrison et al., 2015; Parma et al., 2015) and appetitive conditioning (Abraham et al., 2014) in both humans and rodent models. The present study demonstrates how information about amygdala activity can potentially reach even the OSNs during learning or memory retrieval, providing a potential circuit-level substrate for fear learning-induced changes in stimulus salience. Given the well documented role of NE in enabling learning-related plasticity during fear conditioning in the amygdala (Bush et al., 2010; Johansen et al., 2014), it will be important to investigate whether similar mechanisms drive associative neuroplasticity in sensory regions.

\section{References}

Abraham NM, Vincis R, Lagier S, Rodriguez I, Carleton A (2014) Long term functional plasticity of sensory inputs mediated by olfactory learning. Elife 3:e02109. CrossRef Medline

Adler LE, Hoffer L, Nagamoto HT, Waldo MC, Kisley MA, Giffith JM (1994) Yohimbine impairs P50 auditory sensory gating in normal subjects. Neuropsychopharmacology 10:249-257. CrossRef Medline

Aggleton JP (1993) The contribution of the amygdala to normal and abnormal emotional states. Trends Neurosci 16:328-333. CrossRef Medline

Åhs F, Miller SS, Gordon AR, Lundström JN (2013) Aversive learning increases sensory detection sensitivity. Biol Psychol 92:135-141. CrossRef Medline

Akerboom J, Chen TW, Wardill TJ, Tian L, Marvin JS, Mutlu S, Calderón NC, Esposti F, Borghuis BG, Sun XR, Gordus A, Orger MB, Portugues R, Engert F, Macklin JJ, Filosa A, Aggarwal A, Kerr RA, Takagi R, Kracun S, et al (2012) Optimization of a GCaMP calcium indicator for neural activity imaging. J Neurosci 32:13819-13840. CrossRef Medline

Alsene KM, Bakshi VP (2011) Pharmacological stimulation of locus coeruleus reveals a new antipsychotic-responsive pathway for deficient sensorimotor gating. Neuropsychopharmacology 36:1656-1667. CrossRef Medline

Alsene KM, Rajbhandari AK, Ramaker MJ, Bakshi VP (2011) Discrete forebrain neuronal networks supporting noradrenergic regulation of senso- 
rimotor gating. Neuropsychopharmacology 36:1003-1014. CrossRef Medline

Amaral DG, Price JL (1984) Amygdalo-cortical projections in the monkey (Macaca fascicularis). J Comp Neurol 230:465-496. CrossRef Medline

Aroniadou-Anderjaska V, Zhou FM, Priest CA, Ennis M, Shipley MT (2000) Tonic and synaptically evoked presynaptic inhibition of sensory input to the rat olfactory bulb via GABA(B) heteroreceptors. J Neurophysiol 84: 1194-1203. Medline

Aston-Jones G, Cohen JD (2005) An integrative theory of locus coeruleusnorepinephrine function: adaptive gain and optimal performance. Annu Rev Neurosci 28:403-450. CrossRef Medline

Aston-Jones G, Chiang C, Alexinsky T (1991) Discharge of noradrenergic locus coeruleus neurons in behaving rats and monkeys suggests a role in vigilance. Prog Brain Res 88:501-520. CrossRef Medline

Aston-Jones G, Rajkowski J, Kubiak P, Alexinsky T (1994) Locus coeruleus neurons in monkey are selectively activated by attended cues in a vigilance task. J Neurosci 14:4467-4480. Medline

Aston-Jones G, Rajkowski J, Ivanova S, Usher M, Cohen J (1998) Neuromodulation and cognitive performance: recent studies of noradrenergic locus ceruleus neurons in behaving monkeys. Adv Pharmacol 42:755759. Medline

Aston-Jones G, Rajkowski J, Cohen J (1999) Role of locus coeruleus in attention and behavioral flexibility. Biol Psychiatry 46:1309-1320. CrossRef Medline

Bakshi VP, Alsene KM, Roseboom PH, ConnorsEE (2012) Enduring sensorimotor gating abnormalities following predator exposure or corticotropin-releasing factor in rats: a model for PTSD-like information-processing deficits? Neuropharmacology 62:737-748. CrossRef Medline

Bernard R, Kerman IA, Thompson RC, Jones EG, Bunney WE, Barchas JD, Schatzberg AF, Myers RM, Akil H, Watson SJ (2011) Altered expression of glutamate signaling, growth factor, and glia genes in the locus coeruleus of patients with major depression. Mol Psychiatry 16:634-646. CrossRef Medline

Berridge CW, Waterhouse BD (2003) The locus coeruleus-noradrenergic system: modulation of behavioral state and state-dependent cognitive processes. Brain Res Brain Res Rev 42:33-84. CrossRef Medline

Bouret S, Sara SJ (2002) Locus coeruleus activation modulates firing rate and temporal organization of odour-induced single-cell responses in rat piriform cortex. Eur J Neurosci 16:2371-2382. CrossRef Medline

Bozza T, McGann JP, Mombaerts P, Wachowiak M (2004) In vivo imaging of neuronal activity by targeted expression of a genetically encoded probe in the mouse. Neuron 42:9-21. CrossRef Medline

Brenowitz S, Trussell LO (2001) Minimizing synaptic depression by control of release probability. J Neurosci 21:1857-1867. Medline

Brenowitz S, David J, Trussell L (1998) Enhancement of synaptic efficacy by presynaptic GABA(B) receptors. Neuron 20:135-141. CrossRef Medline

Bush DE, Caparosa EM, Gekker A, Ledoux J (2010) Beta-adrenergic receptors in the lateral nucleus of the amygdala contribute to the acquisition but not the consolidation of auditory fear conditioning. Front Behav Neurosci 4:154. CrossRef Medline

Carmichael ST, Price JL (1995) Limbic connections of the orbital and medial prefrontal cortex in macaque monkeys. J Comp Neurol 363:615-641. CrossRef Medline

Chavez CM, McGaugh JL, Weinberger NM (2013) Activation of the basolateral amygdala induces long-term enhancement of specific memory representations in the cerebral cortex. Neurobiol Learn Mem 101:8-18. CrossRef Medline

Chen C, Regehr WG (2003) Presynaptic modulation of the retinogeniculate synapse. J Neurosci 23:3130-3135. Medline

Chen CF, Barnes DC, Wilson DA (2011) Generalized vs stimulus-specific learned fear differentially modifies stimulus encoding in primary sensory cortex of awake rats. J Neurophysiol 106:3136-3144. CrossRef Medline

Chen TW, Wardill TJ, Sun Y, Pulver SR, Renninger SL, Baohan A, Schreiter ER, Kerr RA, Orger MB, Jayaraman V, Looger LL, Svoboda K, Kim DS (2013) Ultrasensitive fluorescent proteins for imaging neuronal activity. Nature 499:295-300. CrossRef Medline

Chen Y, Li H, Jin Z, Shou T, Yu H (2014) Feedback of the amygdala globally modulates visual response of primary visual cortex in the cat. Neuroimage 84:775-785. CrossRef Medline

Ciombor KJ, Ennis M, Shipley MT (1999) Norepinephrine increases rat mitral cell excitatory responses to weak olfactory nerve input via alpha-1 receptors in vitro. Neuroscience 90:595-606. CrossRef Medline
Czarnecki LA, Moberly AH, Rubinstein T, Turkel DJ, Pottackal J, McGann JP (2011) In vivo visualization of olfactory pathophysiology induced by intranasal cadmium instillation in mice. Neurotoxicology 32:441-449. CrossRef Medline

Czarnecki LA, Moberly AH, Turkel DJ, Rubinstein T, Pottackal J, Rosenthal MC, McCandlish EF, Buckley B, McGann JP (2012) Functional rehabilitation of cadmium-induced neurotoxicity despite persistent peripheral pathophysiology in the olfactory system. Toxicol Sci 126:534-544. CrossRef Medline

Devilbiss DM, Waterhouse BD, Berridge CW, Valentino R (2012) Corticotropin-releasing factor acting at the locus coeruleus disrupts thalamic and cortical sensory-evoked responses. Neuropsychopharmacology 37:2020-2030. CrossRef Medline

Dias BG, Ressler KJ (2014) Parental olfactory experience influences behavior and neural structure in subsequent generations. Nat Neurosci 17:8996. CrossRef Medline

Doucette W, Milder J, Restrepo D (2007) Adrenergic modulation of olfactory bulb circuitry affects odor discrimination. Learn Mem 14:539-547. CrossRef Medline

Eckmeier D, Shea SD (2014) Noradrenergic plasticity of olfactory sensory neuron inputs to the main olfactory bulb. J Neurosci 34:15234-15243. CrossRef Medline

Escanilla O, Arrellanos A, Karnow A, Ennis M, Linster C (2010) Noradrenergic modulation of behavioral odor detection and discrimination thresholds in the olfactory bulb. Eur J Neurosci 32:458-468. CrossRef Medline

Fallon JH, Moore RY (1978) Catecholamine innervation of the basal forebrain. III. Olfactory bulb, anterior olfactory nuclei, olfactory tubercle and piriform cortex. J Comp Neurol 180:533-544. CrossRef Medline

Fanselow MS, Poulos AM (2005) The neuroscience of mammalian associative learning. Annu Rev Psychol 56:207-234. CrossRef Medline

Felmingham KL, Rennie C, Manor B, Bryant RA (2011) Eye tracking and physiological reactivity to threatening stimuli in posttraumatic stress disorder. J Anxiety Disord 25:668-673. CrossRef Medline

Felmingham KL, Rennie C, Gordon E, Bryant RA (2012) Autonomic and cortical reactivity in acute and chronic posttraumatic stress. Biol Psychol 90:224-227. CrossRef Medline

Fletcher ML (2012) Olfactory aversive conditioning alters olfactory bulb mitral/tufted cell glomerular odor responses. Front Syst Neurosci 6:16. CrossRef Medline

Foote SL, Aston-Jones G, Bloom FE (1980) Impulse activity of locus coeruleus neurons in awake rats and monkeys is a function of sensory stimulation and arousal. Proc Natl Acad Sci U S A 77:3033-3037. CrossRef Medline

Franklin KB, Paxinos G (2007) The mouse brain in stereotaxic coordinates, Ed 3. San Diego: Academic.

Fried HU, Kaupp UB, Müller F (2010) Hyperpolarization-activated and cyclic nucleotide-gated channels are differentially expressed in juxtaglomerular cells in the olfactory bulb of mice. Cell Tissue Res 339:463-479. CrossRef Medline

Froemke RC, Martins AR (2011) Spectrotemporal dynamics of auditory cortical synaptic receptive field plasticity. Hear Res 279:149-161. CrossRef Medline

García-Ramírez DL, Calvo JR, Hochman S, Quevedo JN (2014) Serotonin, dopamine and noradrenaline adjust actions of myelinated afferents via modulation of presynaptic inhibition in the mouse spinal cord. PLoS One 9:e89999. CrossRef Medline

Gaucher Q, Edeline JM (2015) Stimulus-specific effects of noradrenaline in auditory cortex: implications for the discrimination of communication sounds. J Physiol 593:1003-1020. CrossRef Medline

George MJ (1992) Modification of receptive fields of posteriomedial barrel subfield neocortical single units by known concentrations of iontophoresed noradrenaline in the rat. Int J Neurosci 65:69-81. CrossRef Medline

Goosens KA, Maren S (2001) Contextual and auditory fear conditioning are mediated by the lateral, basal, and central amygdaloid nuclei in rats. Learn Mem 8:148-155. CrossRef Medline

Gu Q (2002) Neuromodulatory transmitter systems in the cortex and their role in cortical plasticity. Neuroscience 111:815-835. CrossRef Medline

Hammer TB, Oranje B, Glenthoj BY (2007) The effects of imipramine on P50 suppression, prepulse inhibition and habituation of the startle response in humans. Int J Neuropsychopharmacol 10:787-795. CrossRef Medline

Hegerl U, Hensch T (2014) The vigilance regulation model of affective disorders and ADHD. Neurosci Biobehav Rev 44:45-57. CrossRef Medline 
Hendrickson RC, Raskind MA (2016) Noradrenergic dysregulation in the pathophysiology of PTSD. Exp Neurol 284:181-195. CrossRef Medline

Hormigo S, Gómez-Nieto R, Castellano O, Herrero-Turrión MJ, López DE, de Anchieta de Castro E Horta-Júnior J (2015) The noradrenergic projection from the locus coeruleus to the cochlear root neurons in rats. Brain Struct Funct 220:1477-1496. CrossRef Medline

Hurley LM, Devilbiss DM, Waterhouse BD (2004) A matter of focus: monoaminergic modulation of stimulus coding in mammalian sensory networks. Curr Opin Neurobiol 14:488-495. CrossRef Medline

Jiang M, Griff ER, Ennis M, Zimmer LA, Shipley MT (1996) Activation of locus ceruleus enhances the responses of olfactory bulb mitral cells to weak olfactory nerve input. J Neurosci 16:6319-6329. Medline

Johansen JP, Cain CK, Ostroff LE, LeDoux JE (2011) Molecular mechanisms of fear learning and memory. Cell 147:509-524. CrossRef Medline

Johansen JP, Diaz-Mataix L, Hamanaka H, Ozawa T, Ycu E, Koivumaa J, Kumar A, Hou M, Deisseroth K, Boyden ES, LeDoux JE (2014) Hebbian and neuromodulatory mechanisms interact to trigger associative memory formation. Proc Natl Acad Sci U S A 111:E5584-E5592. CrossRef Medline

Johnston BA, Mwangi B, Matthews K, Coghill D, Konrad K, Steele JD (2014) Brainstem abnormalities in attention deficit hyperactivity disorder support high accuracy individual diagnostic classification. Hum Brain Mapp 35:5179-5189. CrossRef Medline

Jones SV, Choi DC, Davis M, Ressler KJ (2008) Learning-dependent structural plasticity in the adult olfactory pathway. J Neurosci 28:1310613111. CrossRef Medline

Kass MD, Pottackal J, Turkel DJ, McGann JP (2013a) Changes in the neural representation of odorants after olfactory deprivation in the adult mouse olfactory bulb. Chem Senses 38:77-89. CrossRef Medline

Kass MD, Moberly AH, McGann JP (2013b) Spatiotemporal alterations in primary odorant representations in olfactory marker protein knockout mice. PLoS One 8:e61431. CrossRef Medline

Kass MD, Moberly AH, Rosenthal MC, Guang SA, McGann JP (2013c) Odor-specific, olfactory marker protein-mediated sparsening of primary olfactory input to the brain after odor exposure. J Neurosci 33:65946602. CrossRef Medline

Kass MD, Rosenthal MC, Pottackal J, McGann JP (2013d) Fear learning enhances neural responses to threat-predictive sensory stimuli. Science 342:1389-1392. CrossRef Medline

Kass MD, Guang SA, Moberly AH, McGann JP (2016) Changes in olfactory sensory neuron physiology and olfactory perceptual learning after odorant exposure in adult mice. Chem Senses 41:123-133. CrossRef Medline

Kayama Y, Negi T, Sugitani M, Iwama K (1982) Effects of locus coeruleus stimulation on neuronal activities of dorsal lateral geniculate nucleus and perigeniculate reticular nucleus of the rat. Neuroscience 7:655-666. CrossRef Medline

Kealy J, Commins S (2011) The rat perirhinal cortex: a review of anatomy, physiology, plasticity, and function. Prog Neurobiol 93:522-548. CrossRef Medline

Kiyokage E, Pan YZ, Shao Z, Kobayashi K, Szabo G, Yanagawa Y, Obata K, Okano H, Toida K, Puche AC, Shipley MT (2010) Molecular identity of periglomerular and short axon cells. J Neurosci 30:1185-1196. CrossRef Medline

Kromer LF, Moore RY (1980a) A study of the organization of the locus coeruleus projections to the lateral geniculate nuclei in the albino rat. Neuroscience 5:255-271. CrossRef Medline

Kromer LF, Moore RY (1980b) Norepinephrine innervation of the cochlear nuclei by locus coeruleus neurons in the rat. Anat Embryol (Berl) 158: 227-244. CrossRef Medline

Krusemark EA, Li W (2013) From early sensory specialization to later perceptual generalization: dynamic temporal progression in perceiving individual threats. J Neurosci 33:587-594. CrossRef Medline

Krusemark EA, Novak LR, Gitelman DR, Li W (2013) When the sense of smell meets emotion: anxiety-state-dependent olfactory processing and neural circuitry adaptation. J Neurosci 33:15324-15332. CrossRef Medline

Kubota T, Anzawa N, Hirota K, Yoshida H, Kushikata T, Matsuki A (1999) Effects of ketamine and pentobarbital on noradrenaline release from the medial prefrontal cortex in rats. Can J Anaesth 46:388-392. CrossRef Medline

Landers MS, Sullivan RM (2012) The development and neurobiology of infant attachment and fear. Dev Neurosci 34:101-114. CrossRef Medline

Lee S, Kim SJ, Kwon OB, Lee JH, Kim JH (2013) Inhibitory networks of the amygdala for emotional memory. Front Neural Circuits 7:129. CrossRef Medline

Li W (2014) Learning to smell danger: acquired associative representation of threat in the olfactory cortex. Front Behav Neurosci 8:98. CrossRef Medline

Li W, Howard JD, Parrish TB, Gottfried JA (2008) Aversive learning enhances perceptual and cortical discrimination of indiscriminable odor cues. Science 319:1842-1845. CrossRef Medline

Light GA, Braff DL (1999) Human and animal studies of schizophreniarelated gating deficits. Curr Psychiatry Rep 1:31-40. CrossRef Medline

Linster C, Nai Q, Ennis M (2011) Nonlinear effects of noradrenergic modulation of olfactory bulb function in adult rodents. J Neurophysiol 105: 1432-1443. CrossRef Medline

Mackintosh NJ (1975) A theory of attention: variations in the associability of stimuli with reinforcement. Psychol Rev 82:276-298. CrossRef

Madisen L, Garner AR, Shimaoka D, Chuong AS, Klapoetke NC, Li L, van der Bourg A, Niino Y, Egolf L, Monetti C, Gu H, Mills M, Cheng A, Tasic B, Nguyen TN, Sunkin SM, Benucci A, Nagy A, Miyawaki A, Helmchen F, et al (2015) Transgenic mice for intersectional targeting of neural sensors and effectors with high specificity and performance. Neuron 85:942-958. CrossRef Medline

Maes M, Lin AH, Verkerk R, Delmeire L, Van Gastel A, Van der Planken M, Scharpé S (1999) Serotonergic and noradrenergic markers of posttraumatic stress disorder with and without major depression. Neuropsychopharmacology 20:188-197. CrossRef Medline

Manella LC, Alperin S, Linster C (2013) Stressors impair odor recognition memory via an olfactory bulb-dependent noradrenergic mechanism. Front Integr Neurosci 7:97. CrossRef Medline

Manunta Y, Edeline JM (1997) Effects of noradrenaline on frequency tuning of rat auditory cortex neurons. Eur J Neurosci 9:833-847. CrossRef Medline

Maren S (2016) Parsing reward and aversion in the amygdala. Neuron 90: 209-211. CrossRef Medline

Maren S, Yap SA, Goosens KA (2001) The amygdala is essential for the development of neuronal plasticity in the medial geniculate nucleus during auditory fear conditioning in rats. J Neurosci 21:RC135. Medline

Martin JH, Ghez C (1999) Pharmacological inactivation in the analysis of the central control of movement. J Neurosci Methods 86:145-159. CrossRef Medline

McGann JP (2013) Presynaptic inhibition of olfactory sensory neurons: new mechanisms and potential functions. Chem Senses 38:459-474. CrossRef Medline

McGann JP (2015) Associative learning and sensory neuroplasticity: how does it happen and what is it good for? Learn Mem 22:567-576. CrossRef Medline

McGann JP, Pírez N, Gainey MA, Muratore C, Elias AS, Wachowiak M (2005) Odorant representations are modulated by intra- but not interglomerular presynaptic inhibition of olfactory sensory neurons. Neuron 48:1039-1053. CrossRef Medline

McLean JH, Harley CW (2004) Olfactory learning in the rat pup: a model that may permit visualization of a mammalian memory trace. Neuroreport 15:1691-1697. CrossRef Medline

McLean JH, Shipley MT, Nickell WT, Aston-Jones G, Reyher CK (1989) Chemoanatomical organization of the noradrenergic input from locus coeruleus to the olfactory bulb of the adult rat. J Comp Neurol 285:339349. CrossRef Medline

Micoulaud-Franchi JA, Vaillant F, Lopez R, Peri P, Baillif A, Brandejsky L, Steffen ML, Boyer L, Richieri R, Cermolacce M, Bioulac S, Aramaki M, Philip P, Lancon C, Vion-Dury J (2015b) Sensory gating in adult with attention-deficit/hyperactivity disorder: event-evoked potential and perceptual experience reports comparisons with schizophrenia. Biol Psychol 107:16-23. CrossRef Medline

Micoulaud-Franchi JA, Lopez R, Vaillant F, Richieri R, El-Kaim A, Bioulac S, Philip P, Boyer L, Lancon C (2015a) Perceptual abnormalities related to sensory gating deficit are core symptoms in adults with ADHD. Psychiatry Res 230:357-363. CrossRef Medline

Miesenböck G, De Angelis DA, Rothman JE (1998) Visualizing secretion and synaptic transmission with $\mathrm{pH}$-sensitive green fluorescent proteins. Nature 394:192-195. CrossRef Medline

Moberly AH, Czarnecki LA, Pottackal J, Rubinstein T, Turkel DJ, Kass MD, McGann JP (2012) Intranasal exposure to manganese disrupts neu- 
rotransmitter release from glutamatergic synapses in the central nervous system in vivo. Neurotoxicology 33:996-1004. CrossRef Medline

Morey RA, Dunsmoor JE, Haswell CC, Brown VM, Vora A, Weiner J, Stjepanovic D, Wagner HR 3rd, LaBar KS (2015) Fear learning circuitry is biased toward generalization of fear associations in posttraumatic stress disorder. Transl Psychiatry 5:e700. CrossRef Medline

Moriceau S, Shionoya K, Jakubs K, Sullivan RM (2009) Early-life stress disrupts attachment learning: the role of amygdala corticosterone, locus ceruleus corticotropin releasing hormone, and olfactory bulb norepinephrine. J Neurosci 29:15745-15755. CrossRef Medline

Morrison FG, Dias BG, Ressler KJ (2015) Extinction reverses olfactory fearconditioned increases in neuron number and glomerular size. Proc Natl Acad Sci U S A 112:12846-12851. CrossRef Medline

Mouly AM, Di Scala G (2006) Entorhinal cortex stimulation modulates amygdala and piriform cortex responses to olfactory bulb inputs in the rat. Neuroscience 137:1131-1141. CrossRef Medline

Murphy GJ, Darcy DP, Isaacson JS (2005) Intraglomerular inhibition: signaling mechanisms of an olfactory microcircuit. Nat Neurosci 8:354-364. CrossRef Medline

Murray EA, Wise SP (2010) Interactions between orbital prefrontal cortex and amygdala: advanced cognition, learned responses and instinctive behaviors. Curr Opin Neurobiol 20:212-220. CrossRef Medline

Nai Q, Dong HW, Hayar A, Linster C, Ennis M (2009) Noradrenergic regulation of GABAergic inhibition of main olfactory bulb mitral cells varies as a function of concentration and receptor subtype. J Neurophysiol 101: 2472-2484. CrossRef Medline

Nakamura M, Suk K, Lee MG, Jang IS (2013) alpha(2A) adrenoceptormediated presynaptic inhibition of GABAergic transmission in rat tuberomammillary nucleus neurons. J Neurochem 125:832-842. CrossRef Medline

Nakashima N, Ishii TM, Bessho Y, Kageyama R, Ohmori H (2013) Hyperpolarisation-activated cyclic nucleotide-gated channels regulate the spontaneous firing rate of olfactory receptor neurons and affect glomerular formation in mice. J Physiol 591:1749-1769. CrossRef Medline

Narayanan NS, Horst NK, Laubach M (2006) Reversible inactivations of rat medial prefrontal cortex impair the ability to wait for a stimulus. Neuroscience 139:865-876. CrossRef Medline

O’Donnell T, Hegadoren KM, Coupland NC (2004) Noradrenergic mechanisms in the pathophysiology of post-traumatic stress disorder. Neuropsychobiology 50:273-283. CrossRef Medline

Okutani F, Zhang JJ, Yagi F, Kaba H (2002) Non-specific olfactory aversion induced by intrabulbar infusion of the GABA(A) receptor antagonist bicuculline in young rats. Neuroscience 112:901-906. CrossRef Medline

Okutani F, Zhang JJ, Otsuka T, Yagi F, Kaba H (2003) Modulation of olfactory learning in young rats through intrabulbar $\mathrm{GABA}(\mathrm{B})$ receptors. Eur J Neurosci 18:2031-2036. CrossRef Medline

Oranje B, Aggernaes B, Rasmussen H, Ebdrup BH, Glenthøj BY (2013) P50 suppression and its neural generators in antipsychotic-naive first-episode schizophrenia before and after 6 months of quetiapine treatment. Schizophr Bull 39:472-480. CrossRef Medline

Ousdal OT, Andreassen OA, Server A, Jensen J (2014) Increased amygdala and visual cortex activity and functional connectivity towards stimulus novelty is associated with state anxiety. PLoS One 9:e96146. CrossRef Medline

Parma V, Ferraro S, Miller SS, Åhs F, Lundström JN (2015) Enhancement of odor sensitivity following repeated odor and visual fear conditioning. Chem Senses 40:497-506. CrossRef Medline

Paz R, Pare D (2013) Physiological basis for emotional modulation of memory circuits by the amygdala. Curr Opin Neurobiol 23:381-386. CrossRef Medline

Pearce JM, Hall G (1980) A model for Pavlovian learning: variations in the effectiveness of conditioned but not of unconditioned stimuli. Psychol Rev 87:532-552. Medline

Pietrzak RH, Gallezot JD, Ding YS, Henry S, Potenza MN, Southwick SM, Krystal JH, Carson RE, Neumeister A (2013) Association of posttraumatic stress disorder with reduced in vivo norepinephrine transporter availability in the locus coeruleus. JAMA Psychiatry 70:1199-1205. CrossRef Medline

Pignatelli A, Borin M, Fogli Iseppe A, Gambardella C, Belluzzi O (2013) The $\mathrm{h}$-current in periglomerular dopaminergic neurons of the mouse olfactory bulb. PLoS One 8:e56571. CrossRef Medline

Pírez N, Wachowiak M (2008) In vivo modulation of sensory input to the olfactory bulb by tonic and activity-dependent presynaptic inhibition of receptor neurons. J Neurosci 28:6360-6371. CrossRef Medline

Price JL, Amaral DG (1981) An autoradiographic study of the projections of the central nucleus of the monkey amygdala. J Neurosci 1:1242-1259. Medline

Rajkowski J, Kubiak P, Aston-Jones G (1994) Locus coeruleus activity in monkey: phasic and tonic changes are associated with altered vigilance. Brain Res Bull 35:607-616. CrossRef Medline

Rescorla RA, Wagner AR (1972) A theory of Pavlovian conditioning: variations in the effectiveness of reinforcement and nonreinforcement. In: Classical conditioning II (Black AH, Prokasy WF, eds), pp 64-99. New York: Appleton-Century-Crofts.

Retson TA, Van Bockstaele EJ (2013) Coordinate regulation of noradrenergic and serotonergic brain regions by amygdalar neurons. J Chem Neuroanat 52:9-19. CrossRef Medline

Reyes BA, Drolet G, Van Bockstaele EJ (2008) Dynorphin and stress-related peptides in rat locus coeruleus: contribution of amygdalar efferents. J Comp Neurol 508:663-675. CrossRef Medline

Rogawski MA, Aghajanian GK (1980) Modulation of lateral geniculate neurone excitability by noradrenaline microiontophoresis or locus coeruleus stimulation. Nature 287:731-734. CrossRef Medline

Rutter JJ, Baumann MH, Waterhouse BD (1998) Systemically administered cocaine alters stimulus-evoked responses of thalamic somatosensory neurons to perithreshold vibrissae stimulation. Brain Res 798:7-17. Medline

Sable JJ, Kyle MR, Knopf KL, Schully LT, Brooks MM, Parry KH, Diamond RE, Flink LA, Stowe R, Suna E, Thompson IA (2012) The Sensory Gating Inventory as a potential diagnostic tool for attention-deficit hyperactivity disorder. Atten Defic Hyperact Disord 4:141-144. CrossRef Medline

Sadrian B, Wilson DA (2015) Optogenetic stimulation of lateral amygdala input to posterior piriform cortex modulates single-unit and ensemble odor processing. Front Neural Circuits 9:81. CrossRef Medline

Salgado H, Garcia-Oscos F, Martinolich L, Hall S, Restom R, Tseng KY, Atzori M (2012) Pre- and postsynaptic effects of norepinephrine on $\gamma$-aminobutyric acid-mediated synaptic transmission in layer $2 / 3$ of the rat auditory cortex. Synapse 66:20-28. CrossRef Medline

Salgado H, Treviño M, Atzori M (2016) Layer- and area-specific actions of norepinephrine on cortical synaptic transmission. Brain Res 1641:163176. CrossRef Medline

Sara SJ (2015) Locus coeruleus in time with the making of memories. Curr Opin Neurobiol 35:87-94. CrossRef Medline

Sato H, Fox K, Daw NW (1989) Effect of electrical stimulation of locus coeruleus on the activity of neurons in the cat visual cortex. J Neurophysiol 62:946-958. Medline

Schwarz LA, Luo L (2015) Organization of the locus coeruleus-norepinephrine system. Curr Biol 25:R1051-R1056. CrossRef Medline

Schwarz LA, Miyamichi K, Gao XJ, Beier KT, Weissbourd B, DeLoach KE, Ren J, Ibanes S, Malenka RC, Kremer EJ, Luo L (2015) Viral-genetic tracing of the input-output organization of a central noradrenaline circuit. Nature 524:88-92. CrossRef Medline

Shao Z, Puche AC, Kiyokage E, Szabo G, Shipley MT (2009) Two GABAergic intraglomerular circuits differentially regulate tonic and phasic presynaptic inhibition of olfactory nerve terminals. J Neurophysiol 101: 1988-2001. CrossRef Medline

Shipley MT, Halloran FJ, de la Torre J (1985) Surprisingly rich projection from locus coeruleus to the olfactory bulb in the rat. Brain Res 329:294299. Medline

Sripanidkulchai K, Sripanidkulchai B, Wyss JM (1984) The cortical projection of the basolateral amygdaloid nucleus in the rat: a retrograde fluorescent dye study. J Comp Neurol 229:419-431. Medline

Stark R, Schienle A, Walter B, Kirsch P, Blecker C, Ott U, Schäfer A, Sammer G, Zimmermann M, Vaitl D (2004) Hemodynamic effects of negative emotional pictures- a test-retest analysis. Neuropsychobiology 50:108118. CrossRef Medline

Steinbach JH, Akk G (2001) Modulation of GABA(A) receptor channel gating by pentobarbital. J Physiol 537:715-733. CrossRef Medline

Sullivan RM, Wilson DA (1991) The role of norepinephrine in the expression of learned olfactory neurobehavioral responses in infant rats. Psychobiology 19:308-312. Medline

Taniguchi H, He M, Wu P, Kim S, Paik R, Sugino K, Kvitsani D, Fu Y, Lu J, Lin Y, Miyoshi G, Shima Y, Fishell G, Nelson SB, Huang ZJ (2011) A re- 
source of Cre driver lines for genetic targeting of GABAergic neurons in cerebral cortex. Neuron 71:995-1013. CrossRef Medline

Taylor SF, Liberzon I, Koeppe RA (2000) The effect of graded aversive stimuli on limbic and visual activation. Neuropsychologia 38:1415-1425. CrossRef Medline

Tjoumakaris SI, Rudoy C, Peoples J, Valentino RJ, Van Bockstaele EJ (2003) Cellular interactions between axon terminals containing endogenous opioid peptides or corticotropin-releasing factor in the rat locus coeruleus and surrounding dorsal pontine tegmentum. J Comp Neurol 466:445456. CrossRef Medline

Valentino RJ, Page M, Van Bockstaele E, Aston-Jones G (1992) Corticotropin-releasing factor innervation of the locus coeruleus region: distribution of fibers and sources of input. Neuroscience 48:689-705. Medline

Van Bockstaele EJ, Colago EE, Valentino RJ (1998) Amygdaloid corticotropin-releasing factor targets locus coeruleus dendrites: substrate for the co-ordination of emotional and cognitive limbs of the stress response. J Neuroendocrinol 10:743-757. Medline

Van Bockstaele EJ, Peoples J, Valentino RJ (1999) A.E. Bennett Research Award. Anatomic basis for differential regulation of the rostrolateral peri-locus coeruleus region by limbic afferents. Biol Psychiatry 46:1352-1363. Medline

van Marle HJ, Hermans EJ, Qin S, Fernández G (2009) From specificity to sensitivity: how acute stress affects amygdala processing of biologically salient stimuli. Biol Psychiatry 66:649-655. CrossRef Medline
Verhagen JV, Wesson DW, Netoff TI, White JA, Wachowiak M (2007) Sniffing controls an adaptive filter of sensory input to the olfactory bulb. Nat Neurosci 10:631-639. CrossRef Medline

Wachowiak M, McGann JP, Heyward PM, Shao Z, Puche AC, Shipley MT (2005) Inhibition of olfactory receptor neuron input to olfactory bulb glomeruli mediated by suppression of presynaptic calcium influx. J Neurophysiol 94:2700-2712. CrossRef Medline

Wachowiak M, Economo MN, Díaz-Quesada M, Brunert D, Wesson DW, White JA, Rothermel M (2013) Optical dissection of odor information processing in vivo using GCaMPs expressed in specified cell types of the olfactory bulb. J Neurosci 33:5285-5300. CrossRef Medline

Waterhouse BD, Sessler FM, Cheng JT, Woodward DJ, Azizi SA, Moises HC (1988) New evidence for a gating action of norepinephrine in central neuronal circuits of mammalian brain. Brain Res Bull 21:425-432. Medline

Waterhouse BD, Azizi SA, Burne RA, Woodward DJ (1990) Modulation of rat cortical area 17 neuronal responses to moving visual stimuli during norepinephrine and serotonin microiontophoresis. Brain Res 514:276292. Medline

Zitnik GA, Clark BD, Waterhouse BD (2013) The impact of hemodynamic stress on sensory signal processing in the rodent lateral geniculate nucleus. Brain Res 1518:36-47. CrossRef Medline 